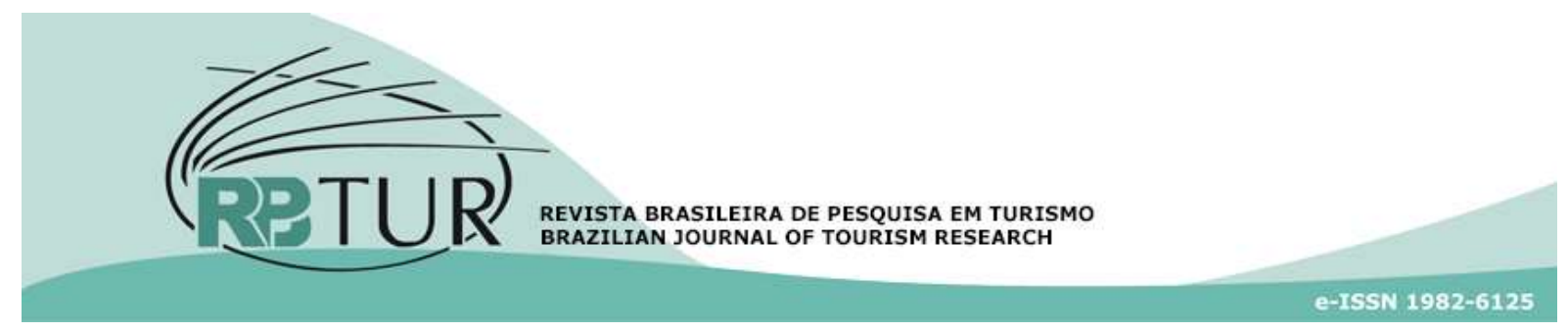

Artigo

DOI: $\underline{\text { http://dx.doi.org/10.7784/rbtur.v12i3.1385 }}$

\title{
Gestão do patrimônio arqueológico e desenvolvimento turístico: ações e propostas
}

\section{Archaeological heritage management and tourism development: actions and proposals}

\section{Gestión del patrimonio arqueológico y desarrollo del turismo: acciones y propuestas}

\author{
Geovan Martins Guimarães ${ }^{1}$ \\ Francisco Antonio Anjos ${ }^{2}$ \\ Deisi Scunderlick Eloy de Farias ${ }^{3}$ \\ Marcos Arnold Junior ${ }^{4}$
}

Resumo: Este artigo apresenta o estado da arte das práticas envolvendo Turismo e Arqueologia em diversas partes do mundo e do Brasil. Teve como objetivo apresentar ações pioneiras de sucesso (ou não) em países com grande potencial arqueológico, como Portugal, Romênia, Turquia, México, República Dominicana, Chile, Brasil, Estados Unidos, entre outros. O método utilizado foi a pesquisa documental e bibliográfica em base de dados, obtidas em meio digital, tendo-se acesso às pesquisas que envolvem o tema do turismo arqueológico na Europa, na América e no Brasil. Como resultado, foram identificados os fatores que nortearam essas ações e foi proposto um modelo de referência para a gestão do patrimônio arqueológico, podendo-se utilizar o Turismo como instrumento de divulgação, proteção, sustentabilidade e integração com a comunidade local.

Palavras-chave: Turismo. Gestão do patrimônio arqueológico. Modelo de Gestão.

Abstract: This article presents the state of the art of practices involving Tourism and Archeology, in various parts of the world and in Brazil. It aimed to present successful and not so successful cases of pioneering actions in

${ }^{1}$ Universidade do Sul de Santa Catarina (UNISUL). Tubarão (SC). Brasil. Desenvolvimento da proposta inicial da pesquisa. Revisão da literatura; Análise e discussão da proposta do artigo. Revisão Final.

2 Universidade do Vale do Itajaí (UNIVALI). Balneário Camboriú (SC). Brasil. Desenvolvimento da proposta inicial da pesquisa. Revisão da literatura; Análise e discussão da proposta do artigo. Revisão Final.

${ }^{3}$ Universidade do Sul de Santa Catarina (UNISUL). Tubarão (SC). Brasil. Revisão da literatura; Análise e discussão da proposta do artigo.

${ }^{4}$ Universidade do Sul de Santa Catarina (UNISUL). Tubarão (SC). Brasil. Revisão da literatura; Análise e discussão da proposta do artigo. Revisão final do texto em Inglês.

Artigo recebido em: 18/11/2017. Artigo aceito em: 14/06/2018.

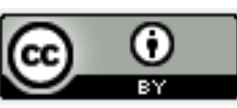


countries with high archaeological potential such as Portugal, Romania, Turkey, Mexico, Dominican Republic, Chile, Brazil, United States, among others. The methods used were the documentary research and bibliographical research in databases, obtained in digital media, willing to find researches involving the subject of archeological tourism in Europe, America and Brazil. As a result, the factors guiding these actions were identified and a reference model for archaeological heritage management was built so it can be used as an instrument of dissemination, protection, sustainability and integration with the local community.

Keywords: Tourism and Archaeological Heritage Management. Management Model.

Resumen: Este artículo presenta el estado del arte de las prácticas involucrando Turismo y Arqueología, en diversas partes del mundo y de Brasil. Tuvo como objetivo presentar las acciones pioneras exitosas o no, en los países con alto potencial arqueológico como Portugal, Rumania, Turquía, México, República Dominicana, Chile, Brasil, Estados Unidos, entre otros. El método utilizado fue el documental y la base de investigación bibliográfica de datos, obtenidos en medio digital, donde se tuvieron acceso a las investigaciones que involucran el tema del turismo arqueológico en Europa, América y Brasil. Como resultado se identificaron los factores que guiaron estas acciones y propuesto un modelo de referencia, para la gestión del patrimonio arqueológico, que puede utilizarse del Turismo como un instrumento de divulgación, protección, sostenibilidad e integración con la comunidad local.

Palabras clave: Turismo y Gestión del patrimonio arqueológico. Modelo de Gestión. Estudios de caso.

\section{APRESENTAÇÃO}

A discussão sobre a gestão do patrimônio arqueológico tem se expandido por diversas partes do mundo. Em alguns países esse movimento ganha força por questões políticas, pois locais em conflito buscam apoio nos órgãos internacionais e em suas diretrizes para proteger o patrimônio cultural. Em outros, o destaque fica por conta do fator econômico, cujo Turismo se caracteriza como elemento dinamizador do processo de proteção. Diversas normas e diretrizes foram elaboradas ao longo dos anos nos mais diversos países. A Carta de Veneza (1964), por exemplo, adverte que, apesar da ocorrência de medidas intergovernamentais que promovem a ação global, não se pode perder de vista a aplicação efetiva de cada Estado, no que compete à preservação e à salvaguarda do patrimônio arqueológico e cultural.

Este artigo apresenta os estudos de casos que envolvem a relação entre turismo e patrimônio arqueológico apresentados pela literatura. Inicialmente, serão apresentados casos de países da Europa; posteriormente, de outros países da América e, por fim, os casos brasileiros.

Diversos autores dissertaram sobre o tema, destacando-se Copeta e Giocomo (2010), que discutem a criação de rotas turísticas, integrando diversos patrimônios culturais, entre eles, sítios arqueológicos. Chivu (2013) e Ramíres, Novella e Barreira-Bassols (2010) enfatizam a importância do turismo planejado como alternativa à proteção do patrimônio local frente ao desenvolvimento desordenado. Em se tratando de participação entre o poder público e a iniciativa privada, Shoup, Baraldi e Zan (2010) indicam possibilidades para essa integração; Villalobos (2014), bem como Sugiura e Nieto (2014), apresentam reflexões sobre a visibilidade desigual dada ao patrimônio arqueológico, que, por falta de proteção legal ou mesmo do estabelecimento de identidade, relegam parte do seu patrimônio ao abando- 
no; Griffith e Griffith (2013), Ayala (2015) e Endere e Zulaica (2015) reforçaram em suas pesquisas a importância da participação da população local no processo de planejamento e gestão do patrimônio arqueológico; Guidon (2007), Veloso e Cavalcanti (2007), Buco (2012) e Chamas e Schimidt (2011) discutem a utilização do patrimônio arqueológico como atrativo turístico a partir de casos brasileiros. Estes, entre outros autores, contribuíram para a concepção dessa pesquisa.

A relevância desse levantamento do estado de conhecimento teve como desafio mapear, por meio de pesquisa bibliográfica, e discutir as principais investigações envolvendo Turismo e Patrimônio Arqueológico em diferentes épocas e lugares sob enfoques teóricos e metodológicos diversos. Esse levantamento possibilitou o desenvolvimento de um novo postulado apresentado aqui como o Modelo Referen-cial de Gestão para o desenvolvimento do Turismo em sítios arqueológicos.

Com esse levantamento foi possível realizar análises aliadas a outros referenciais bibliográficos, o que possibilitou a promoção e a definição das categorias referenciais do modelo de gestão para o desenvolvimento do turismo em sítios arqueológicos, objetivo principal desta reflexão.

\section{TURISMO E GESTÃO DO PATRIMÔNIO NA EUROPA}

\subsection{Portugal - Península de Tróia}

Turismo e Gestão do Patrimônio fazem parte do movimento econômico de vários países da Europa. Como exemplo, tem-se o caso apresentado no artigo de Silveira, Kraus, Psuty, \& Andrade (2011) sobre a reconstrução de praia, com a recomposição da faixa de areia na Península de Tróia, em Portugal, que resultou em uma nova modelagem da praia, onde um dos pontos recompostos foi junto a edificações do período romano. A ação criou uma área mais extensa, com uma zona de amortecimento que possibilitou a proteção da edificação, que estava em risco de destruição pela ação do mar. Uma das obras implantadas no local foi uma marina, cujo sedimento da dragagem foi utilizado no aumento da praia. A partir de outubro de 2006, os sedimentos começaram a ser depositados em quatro setores distintos da região, visando à restauração da praia. Em um desses pontos estava o sítio arqueológico do período romano.

Durante o monitoramento observouse a movimentação do sedimento, já que a faixa de areia criada em frente ao sítio arqueológico funcionava como uma zona de amortecimento. Duas vezes por ano era realizado o levantando batimétrico, visando ao monitoramento da área da marina, onde eram realizadas eventuais dragagens para a manutenção da praia.

\subsection{Itália - sul da península Itálica}

Na Itália, o geógrafo e monge Guidone descreveu, no ano de 1119, uma rota medieval que passava por Apúlia e Basilicata, ao sul da península itálica. Realizou uma viagem por trilhas para visitar centros religiosos, igrejas de pedra do período medieval, sítios arqueológicos e paisagens rurais, tais como a Abadia de Montescaglioso e as ruínas de Gru- 
mentum. A revitalização do caminho percorrido por Guidone para além de uma rota turística é vista como uma oportunidade de envolver a comunidade local, valorizando identidades e tradições locais (Copeta \& Giacomo, 2010, p. 111).

De acordo com Copeta e Giacomo (2010, p. 111), a revitalização da rota medieval contribui para o desenvolvimento cultural, econômico e social, com o incremento do turismo responsável, podendo esses atrativos trazer benefícios ao patrimônio e à comunidade local.

A partir das descrições de Guidone, uma proposta foi apresentada. Estabeleceuse uma rota que passava por locais com características e valores ambientais, paisagísticos e culturais peculiares, como pequenos centros medievais, conventos, igrejas em pedra, ruínas e áreas rurais, caracterizando um território com muitos elementos singulares. As atividades turísticas propostas envolvem caminhadas, trekking, trens regionais e passeios de bicicleta, representando uma modalidade ímpar para a região. Para visitá-la, o viajante teria que ter disponibilidade de tempo para a viagem. Ao longo da rota se organizariam paradas entre 10 e $15 \mathrm{~km}$, privilegiando os centros históricos dotados de estrutura básica para recepcionar o visitante. Quando não fosse possível utilizar essa estratégia, novas estruturas precisariam ser instaladas (Copeta \& Giacomo, 2010, p. 116).

Para o desenvolvimento dessa rota, consideraram-se alguns princípios de uma gestão eficiente. Copeta e Giocomo (2010) destacam ações que deverão ser utilizadas no desenvolvimento do projeto, como o envolvimento de órgãos públicos e privados; in- centivo ao surgimento de novas empresas e postos de trabalho; qualificação da população e dos operadores turísticos locais, visando à melhora no serviço receptivo; participação em feiras e elaboração de material promocional sobre o patrimônio local; envolvimento de operadores turísticos para criação de redes de compartilhamento de boas práticas e experiências.

O trabalho reforça a importância do desenvolvimento de um turismo alternativo, com foco no desenvolvimento regional, integrando a população e promovendo a revitalização do patrimônio cultural local. As atividades turísticas propostas poderão ser uma alternativa à sazonalidade do turismo regional, podendo ser desenvolvidas em diferentes estações do ano, o que incrementaria outros segmentos turísticos existentes na região.

\subsection{Romênia - Rosia Montana, na região da Transilvânia}

Chivu (2013) apresentou um estudo de caso do município de Rosia Montana, na Romênia, onde havia a perspectiva de ser implantado um projeto de mineração, o que colocaria em risco o patrimônio histórico regional. Diante deste quadro, o turismo passou a ser visto como uma possibilidade de incremento de renda para a população e contribuiria para a preservação do patrimônio natural e cultural. Além do foco na preservação do patrimônio natural e cultural, pretendia-se que o turismo fosse uma alternativa para a economia local, baseada na mineração.

Rosia Montana foi construída em virtude da mineração. Documentos comprovam que sua fundação ocorreu há quase 2.000 
anos, constituindo o mais antigo assentamento de mineração da Europa. Ali são encontradas galerias dos períodos romano, medieval e moderno (pré-industrial), apresentando testemunhos dos diferentes ciclos de mineração da região.

The Roman galleries were built through a unique technique, in trapezoidal shape. Most Roman galleries are located in Orlea Massif, some of them being open to visitors. They possess a universal value as they relate to the history and culture of the Roman Empire. Other Roman artifacts are represented by the remains of religious or administrative buildings, or funeral relics (sarcophagi, tombstones), and traces of Roman roads which connected the ancient Roșia Montană (Alburnus Maior) to other mining centers in the area. The ancient Mausoleum represents a remarkable attracttion, a double circular tomb, the only one of this kind discovered in Romania from the Dacian-Roman period (Chivu, 2013, p. 45).

Os elementos arquitetônicos encontrados em Rosia Montana também têm suas particularidades e revelam sinais da história e do desenvolvimento econômico local. Em se tratando do patrimônio arquitetônico, percebe-se um local com variações nos estilos, desde estruturas tradicionais mais simples até as mais detalhadas, demonstrando certo poder.

Chivu (2013) enfatizou o turismo como elemento para o desenvolvimento econômico. No entanto, ele indica a necessidade de as atividades turísticas estarem atreladas, simultaneamente, com a promoção, a infraestrutura geral, o quadro legislativo, o pro- grama de conservação e o uso sustentável dos recursos.

No caso em foco, constata-se uma luta constante na valorização do patrimônio local. Uma das primeiras ações nesse sentido ocorreu com restauração dos edifícios históricos por especialistas. Os materiais utilizados obedeceram às técnicas construtivas originais, utilizando-se materiais como argila, areia, calcário, pedra e madeira e evitando materiais como cimento e metal. Isso só foi possível devido ao envolvimento de alunos de arquitetura e com o auxílio da comunidade local. A principal empresa interessada na mineração também restaurou edifícios históricos, mas foi contestada por especialistas por não utilizarem elementos originais.

Visando à maior valorização do patrimônio local, foi criado um festival anual, que reúne uma série de atividades como seminários, workshops e passeios. Com o passar dos anos, o evento está atraindo muitos participantes que, por carência de hospedagem tradicional, se acomodam nas propriedades de moradores locais, promovendo a geração de renda e a valorização da cultura local.

\subsection{Turquia - modelo de gestão do setor de cultura}

O governo turco adotou um modelo de gestão do setor de cultura por meio da terceirização dos serviços comerciais, mas sem perder o controle da administração pública, que combina a flexibilidade dos contratos do setor privado e a continuação da gestão administrativa centralizada no poder público (Shoup, Baraldi \& Zan, 2014). 
Apesar desse modelo de participação privada na gestão do patrimônio cultural, as decisões são centralizadas no Ministério de Cultura e Turismo (Ministry of Culture and Tourism - MoCT). Além do Ministério, a Direção Geral do Patrimônio Cultural e Museus (General Directorate of Cultural Heritage and Museums - GDCHM) e a Direção de Museus são entidades regionais que gerenciam museus e ruínas, protegem os locais tombados e conduzem e monitoram as escavações. Possuem pouca autonomia quanto a orçamentos e regras de trabalho. Em 2009, havia 102 desses órgãos controlando 183 museus e 127 ruínas abertas ao público (Shoup et al., 2014).

Apesar da receita do MoCT ser positiva, uma estratégia de remanejamento de uma quantidade significativa dos funcionários para outras áreas do governo, aliada ao despreparo do staff (como desconhecimento de línguas estrangeiras e desqualificação dos serviços prestados), foi ponto destacado no estudo. Os prestadores de serviço possuíam pouca experiência na área em turismo, aliada à falta de uma estratégia eficiente de marketing, promoção e identidade bem definida, limitando os resultados positivos da iniciativa (Shoup et al., 2014).

A pesquisa de Shoup et al. (2014) teve como principal objetivo a análise de três contratos de terceirização no setor de cultura do governo turco, executados entre os anos de 2009 e 2010. Os contratos terceirizavam os serviços comerciais em museus e sítios arqueológicos, que se constituem na maior arrecadação de renda da Direção Central de Fundos Rotativos (Döner Sermaye iş̧letmesi Merkez Müdürlüğü - Dösim), o principal ór- gão de financiamento de atividades ligadas ao patrimônio cultural.

No ano de 2009, um primeiro contrato entre a Associação Turca de Agências de Viagens (Turkish Association of Travel Agents - Türsab) e Dösim foi assinado. Essa ação, uma espécie de programa piloto, objetivava a modernização do Museu Arqueológico de Istambul (Istambul Archaeology Museum - IAM). O modelo IAM/Türsab foi substituído por outros dois contratos de terceirização mais abrangentes: um realizado no ano de 2009, permitindo a construção e a operação de lojas de presentes e cafés; e outro no ano de 2010, que viabilizaria a modernização e a operação de catracas. Cada contrato incluía um pacote de cerca de 50 museus e ruínas.

De acordo com os pesquisadores, essas medidas foram necessárias devido às dificuldades administrativas apresentadas pelo Dösim. Cita-se como exemplo o IAM, que em meados de 2000 apresentava problemas de baixa qualidade no serviço prestado aos visitantes, instalações insuficientes e envelhecimento da infraestrutura. Essa situação foi agravada pela falta de autonomia no orçamento e pelo número insuficiente de colaboradores. O contrato do Projeto de Desenvolvimento do IAM, assinado pela Türsab em 2009, focava na resolução dos problemas enfrentados pelo museu. O contrato incluía a reconstrução do museu, seguindo as normas internacionais, apoio a projetos científicos, resolução de problemas com recursos humanos, curadoria e desenvolvimento de coleções, melhoria dos serviços ao visitante, aumento no número de visitas, desenvolvimento do turismo cultural, entre outros. 
Também no ano de 2009 foi celebrado o contrato com Bilkent Kültür Geliştirme (BKG), com o objetivo de terceirizar a gestão das lojas de cafés em museus e ruínas. Uma das exigências do Estado nesse contrato foi a venda de produtos dos artesãos nacionais.

O último contrato analisado foi decorrente da licitação das bilheterias. A empresa vencedora teria, dentre outras vantagens, a responsabilidade de criar um sistema seguro de controle de acesso de visitantes, além do cartão de museus. Nos primeiros meses de funcionamento, registrou-se um aumento significativo de visitantes, interpretado pelo Dösim não como um aumento real, mas como resultado do controle maior na entrada. O número de pessoas que visitam o lugar ainda é crescente, certamente em decorrência das campanhas de marketing e melhorias de serviços oferecidos aos visitantes após as mudanças realizadas na gestão do local. 0 governo exigiu que as lojas de presentes revendessem artesanato de fabricação nacional. Os produtos deveriam ser relacionados ao patrimônio local e à identidade do patrimônio cultural nacional.

Partindo de um discurso de modernização e de maior transparência, o modelo turco de terceirização desvinculava a descentralização, ampliando a capacidade gerencial dentro de um estado controlador. Este modelo de terceirização sem descentralização é bastante distinto, mas, de acordo com os autores, oferece algumas reflexões interessantes no debate sobre a nova gestão pública e a transformação do setor público em diferentes países (Shoup et al., 2014, p. 74).
O modelo mostra-se controlador, pois o órgão governamental responsável pelo patrimônio pode fazer o acompanhamento da atividade em tempo real por meio de um sistema moderno de monitoramento. Shoup et al. (2014, p. 74) descrevem que, nesse modelo, a criatividade da abordagem ofereceu elementos para modernizar, evitando interferir em uma tradição administrativa bastante centralizadora.

Uma questão-problema apontada por Shoup et al. (2014) foi o processo de terceirização que ocorreu de forma verticalizada. Os contratos de concessão foram realizados por tipologia de serviço, em blocos, compostos por uma série de museus e sítios arqueológicos de várias regiões do país. Este modelo tem pouca participação local e ainda gera o monopólio do serviço. Talvez o resultado fosse diferente, caso a terceirização ocorresse por regiões. Os serviços seriam mais distintos, oportunizando mais autonomia para o museu ou sítio arqueológico nos locais de sua ocorrência. Para Shoup et al. Baraldi e Zan (2014), o modelo demostra certa eficiência na gestão, resolvendo os problemas que centros de visitação vinham enfrentando, porém destacam o caráter negativo da terceirização verticalizada.

O estudo de caso da terceirização de serviços do patrimônio cultural da Turquia é um bom exemplo de que parcerias públicoprivadas podem ser uma alternativa para o planejamento e para a gestão do turismo arqueológico. Por conta da flexibilização da gestão, o setor privado poderia dar respostas mais rápidas às necessidades da atividade, driblando a morosidade do serviço público. 


\section{TURISMO E GESTÃO DO PATRIMÔNIO NA AMÉRICA}

\subsection{México - modelo de turismo cultural}

Um estudo de caso apresentado por Ramírez, Novella e Barrera-Bassols (2010) tem foco na conservação para paisagem e geossítios na costa norte de Michoacán. Os autores consideram o patrimônio e a sua conservação um tema atual como estratégia importante para preservar a natureza e os vestígios do passado. Destacam que ainda ocorre e degradação de sítios arqueológicos causada por saques ao patrimônio, fomentados pelo comércio ilegal. Além disso, há a deterioração causada pelo mau uso do patrimônio; a negligência e a fragilidade do bem não renovável (quando usado inadequadamente), pondo em risco o patrimônio cultural mexicano. Uma visão progressista de ocupação, sem a atenção adequada, visou apenas ao benefício econômico. A urbanização desordenada, a abertura de rodovias, o aumento do número de visitantes, o vandalismo, o empobrecimento da população local e seu distanciamento do patrimônio arqueológico amplificam o problema (Ramírez et al., 2010, p. 106).

A conservação da paisagem e dos sítios arqueológicos pode ser atingida com medidas preventivas e de adequação, integrando as populações locais na gestão do patrimônio. Assim, medidas devem ser tomadas para reforçar os laços de identidade, os quais se fortalecem, principalmente quando há descendentes diretos ligados ao patrimônio, como ocorre em Michoacán, onde os sítios arqueológicos são parte da cultura na cestral dos atuais habitantes da região (Ramírez et al., 2010, p. 106). Ramírez et al. (2010, p. 106) reforçam que a proposta deve oferecer recursos conceituais e técnicos de como o patrimônio será estudado e apresentado ao público.

Outro exemplo a ser destacado é dos sítios de grupos ceramistas portadores da cultura Capacha, os quais deixaram vestígios de sua ocupação em uma área significativa da costa do Pacífico, uma área pertencente a seis Estados mexicanos: Sinaloa, Nayarit, Jalisco, Colima, Michoacán e Guerrero. A pesquisa ocorreu no município de Coahua-yana, onde as investigações arqueológicas ainda são incipientes, bem como os estudos relacionados ao meio físico. Ramírez et al. (2010) desenvolveram a pesquisa em quatro sítios arqueológicos com datas entre 300 e 1200 d.C., possuindo como característica comum o fato de terem sido muito depredados por caçadores de tesouros. Ramírez et al. (2010, p. 118) também chamam a atenção para os processos naturais e antrópicos de destruição dos sítios, como terremotos, furacões e inundações fluviais.

A investigação apresentou os elementos da paisagem cultural e natural, abordando as características dos sítios arqueológicos integrados ao meio físico. Uma ferramenta fundamental no processo foi o Sistema de Informações Geográfica (SIG), utilizado como plataforma de gestão das informações coletadas previamente, juntamente com os dados de campo. Com a informação integrada no SIG, analisaram-se espacialmente as particularidades dos elementos, que compunham a paisagem, e coletaram-se informações integradas da composição da 
paisagem natural e cultural, quando se produziram as seguintes categorias de análise: a) paisagem com grande potencial para a conservação da diversidade sociocultural; b) conservação da excepcionalidade da paisagem com importante sítio arqueológico; c) conservação da biodiversidade; d) conservação de um importante sítio arqueológico (Ramírez et al., 2010, p. 116). Por fim, Ramírez et al. (2010, p. 118) reforçam que o conceito de gestão dos recursos, amplamente difundido em estudos ambientais e ecológicos, pode ajustar-se ao patrimônio geobiocultural.

Outra área estudada foi a de Quintana Roo, uma região turística bastante visitada e promovida pelo governo do México, outrora ocupada por grupos da cultura Maia. Ali há sítios arqueológicos compostos por estruturas monumentais que datam entre 564 a 1400 anos d.C. Além de um patrimônio cultural significativo, a região possui um patrimônio natural disputado, pois está localizada na costa do Caribe, cujo turismo de praia é bastante desenvolvido. Na região, treze sítios arqueológicos são abertos à visitação e a gestão é realizada pelo Instituto Nacional de Antropologia e História (INAH) (Villalobos, 2014, p. 226).

Ainda no México, no golfo da Califórnia, encontra-se Sonora, um destino bastante recorrente para estadunidenses. O local possuiu uma gama variada de segmentos turísticos, além de sol e mar, campos de golfe, ecoturismo, pesca esportiva, entre outros. Nessa região, encontram-se registrados aproximadamente 3 mil sítios arqueológicos, filiados a diferentes culturas.

Villalobos (2014, p. 242) avalia que, no México, arqueologia, nacionalismo e turismo estabeleceram relações recíprocas, devido ao significativo legado cultural daquele país. Ali se criou um panteão mítico ligado a culturas diversas, destacando-se as que deixaram um patrimônio cultural monumental. No entanto, Villalobos (2014) adverte que, no México, a promoção do turismo estabelece uma relação desigual com o patrimônio nacional. $O$ estudo critica as políticas nacionalistas à medida que esta busca criar uma identidade nacional, valoriza certas culturas como representativas, eliminando a diversidade. A desvalorização de sítios carentes de vestígios monumentais coloca em risco o patrimônio arqueológico de pequeno porte, que, segundo Sugiura e Nieto (2014), não estão protegidos legalmente, condenando-os à destruição em função da urbanização desenfreada, atividades de mineração, entre outras.

Como alternativa à situação, Sugiura e Nieto (2014), a partir do estudo de caso de Santa Cruz Atizapán, apresentam uma proposta para o registro e salvaguarda dos sítios arqueológicos de pequena escala, por meio da criação de uma base de dados que contém: estudos cartográficos, bibliográficos, etnográficos, fotografias antigas, imagens aéreas, levantamentos sistemáticos da área e, quando possível, dados de escavação arqueológica e de amostragens sistemáticas em pequenas áreas, os quais permitam responder questões essenciais sobre a história do sítio. Métodos geofísicos também foram aplicados, como gradiente magnético, resistividade elétrica e radar de penetração, possibilitando imagear o subsolo. 


\subsection{Guatemala - Parques Arqueológicos}

$\mathrm{Na}$ Guatemala, dados governamentais indicam a presença de mais de 3.000 sítios arqueológicos do período pré-colonial, que somados aos sítios históricos, ampliam o número de monumentos reconhecidos como patrimônio no país. Chavarría (2012) apresenta um estudo demonstrando o vínculo entre turismo e cultura a partir dos parques arqueológicos da Guatemala e avalia que, apesar desse número significativo de sítios arqueológicos, apenas alguns estão sob a vigilância efetiva do governo:

De la totalidad de sitios registrados hasta el momento, el Ministerio de Cultura y Deportes de Guatemala mantiene vigilancia en al menos 100 sitios arqueológicos de los cuales 29 tienen la categoría de parque por contar con la infraestructura básica para atender al turismo. Arqueológicamente Guatemala se divide en tres grandes zonas: Costa Sur, Tierras Altas y Tierras Bajas (Chavarría, 2012, p. 42).

Segundo Chavarría (2012), os parques arqueológicos são vistos como importantes veículos de integração entre cultura e turismo, formando parte da identidade nacional daquele país. Na perspectiva cultural, esses parques se caracterizam como símbolos de um passado histórico, ainda latente nas sociedades guatemaltecas. No âmbito do turismo, eles atraem milhares de pessoas de diversas partes do mundo: "Según los datos del Instituto Guatemalteco de Turismo, en 2011 el país recibió aproximadamente casi 2 millones de visitantes extranjeros." (Chavarría, 2012, p. 44).

\subsection{República Dominicana - Cueva Borbón e Cueva de las Maravillas}

Nesse país, destacam-se os sítios arqueológicos Cueva Borbón e Cueva de las Maravillas, apresentados por Griffith e Griffith (2012, p. 523). Trata-se de um caso emblemático, que graças a uma forte mobilização e a um programa controverso de desenvolvimento do turismo, foi impedido de ser executado. Trata-se de cavernas com pinturas rupestres e petroglifos, entre outros vestígios testemunhos da ocupação humana pré-colonial. Sem a consulta de especialista em patrimônio arqueológico, um programa para o desenvolvimento do turismo pôs em risco a integridade dos sítios. Frente aos problemas detectados, buscaram contorná-los por meio de iniciativas participativas, trabaIhando com stakeholders e soluções para conservar e preservar o patrimônio frente ao avanço do turismo desordenado. Inicialmente, o programa foi executado na Cueva de las Maravillas e, posteriormente, na Cueva Borbón.

O programa desenvolvido na Cueva de las Maravillas exemplifica uma série de práticas e intervenções que não devem ser desenvolvidas sob hipótese alguma em sítios arqueológicos. As intervenções realizadas por equipe sem qualificação causaram danos diretos e indiretos ao patrimônio.

As interferências realizadas para o desenvolvimento da atividade turística no local ameaçaram o patrimônio cultural e a sua biodiversidade. Ações realizadas na área interna modificaram o ambiente, como utilização de maquinários para nivelar o piso e ampliar os ambientes. A poeira proveniente da 
obra cobriu as pinturas rupestres e, para contê-la, a equipe cobriu-as com folhas plásticas, expondo os vestígios arqueológicos a um microclima nefasto, já que o ar foi condensado, umidificando o local. Foram construídas calçadas e escadas de cimento, um sistema de iluminação impróprio foi instalado, pondo em risco as pinturas e favorecendo o surgimento de fungos e algas. Posteriormente, um plano de desenvolvimento semelhante foi iniciado na Cueva Bórbon. Contudo, um movimento contrário ao programa tomou corpo, com os flagrantes de perturbação de vestígios arqueológicos registrados e o apoio de organismos internacionais, levando o projeto ao abandono (Griffith \& Griffith, 2012).

Inúmeras críticas foram feitas por órgãos especializados. Em função dessas ingerências, o reconhecimento do patrimônio por organismos internacionais correu o risco de ser inviabilizado. Mesmo com todos os protestos, o programa na Cueva de las Maravillas não foi interrompido e a caverna foi aberta para a atividade turística (Griffith \& Griffith, 2012, p. 526).

Frente aos acontecimentos, Griffith e Griffith (2012) sugerem uma proposta a ser desenvolvida na Cueva Borbón, primando pelo envolvimento da população local para o desenvolvimento turístico. Logo, é necessário saber qual o interesse da população frente ao desenvolvimento do turismo na caverna, identificando as iniciativas consideradas importantes. $O$ foco de interesse é qualificar a população para a valorização do patrimônio, com indivíduos capazes de divulgar sua própria história, inclusive desenvolvendo ferramentas para a apresentação de elemen- tos de identidade e memória. Nesta situação, a atuação de especialistas em turismo e arqueologia desempenharia o papel de educadores (Griffith \& Griffith, 2012, p. 530).

A intenção da proposta foi permitir que a população pudesse desenvolver suas próprias narrativas sobre o seu patrimônio, promovendo a proteção, o respeito às regras e aos regulamentos e a denúncia de atos depredatórios. O intuito foi proporcionar independência para o desenvolvimento da atividade, sem a atuação contínua de um especialista (Griffith \& Griffith, 2012, p. 531)

Esse estudo de caso das Cuevas de la Maravillas e Cueva Borbón, na República Dominicana, demonstrou que ações impositivas da atividade turística sem o envolvimento da sociedade local distanciam ainda mais a comunidade dos sítios arqueológicos. Entretanto, esses problemas podem ser revertidos com programas de qualidade, que privilegiem a salvaguarda do patrimônio e o envolvimento da comunidade local.

\subsection{Equador - Sítio arqueológico Agua Blanca}

No Equador, Endere e Zulaica (2015) apresentam um estudo sobre o sítio arqueológico Agua Blanca, localizado no Parque $\mathrm{Na-}$ cional de Machalilla, na comunidade homônima, no Cantão de Puerto Lopez, na província de Manabi. Agua Blanca é a atração mais popular do parque, com sítio arqueológico, museu e um lago de água sulforosa com propriedades medicinais.

O sítio arqueológico constitui-se de várias estruturas em rocha, vestígios atribuídos aos grupos das culturas Valdivia, Macha- 
lilla, Chorrera, Bahía, Guangala e Manteña. Apenas parte do sítio pode ser visitado. Nas trilhas, há informações sobre o patrimônio e em alguns locais com estruturas arqueológicas mais extensas foram instaladas infraestruturas de proteção. 0 museu expõe materiais cerâmicos, líticos, ósseos, entre outros, os quais representam o contexto arqueológico do local. As peças que compõem a mostra são provenientes de escavações arqueológicas daquele sítio, como também há relato de um artefato arqueológico doado por um morador da comunidade que, motivado pela iniciativa da musealização, entregou um banco esculpido em pedra, o qual deu origem à identidade visual do local (Endere \& Zulaica, 2015, p. 262-263).

A Constituição equatoriana de 2008 estabeleceu as regras para o Buen Vivir ou sumak kawsay ${ }^{5}$. O Buen Vivir é entendido como "as a platform, a common space where different ontologies can coexist and from where to build the interculturality that aims at generating alternatives to development" (Endere \& Zulaica, 2015, p. 259).

A pesquisa desenvolvida por Endere e Zulaica (2015, p. 260) analisou o caso de Agua Blanca a partir das políticas e das orientações do Plano Nacional para o Bem Viver ${ }^{6}$ 20132017. O Plano está organizado em três áreas: I- Mudança da relação de poder para a construção de um poder popular; II - Direitos, liberdade e capacidades para o Bem Viver; II Transformação econômica para a mudança da matriz produtiva (Endere \& Zulaica, 2015, p. 260).

\footnotetext{
${ }^{5}$ Termo em Quechua, língua indígena sul americana.
}

A proposta da pesquisa foi definir os aspectos que devem ser considerados na avaliação da sustentabilidade sociocultural do sítio arqueológico do Centro Comunitário de Turismo de Agua Blanca e analisar a sustentabilidade das políticas e orientações do plano Bem Viver 2013-2017 (Endere \& Zulaica, 2015, p. 260).

A escolha desse sítio ocorreu por se tratar de um caso de referência nacional, cuja comunidade nativa esteve engajada na preservação do patrimônio, inclusive justificando a presença deste em um parque nacional (Endere \& Zulaica, 2015, p. 260).

As pesquisas arqueológicas indicam que a ocupação do sítio ocorreu entre os anos de 800 e 1532 d.C., período em que colonizadores espanhóis chegaram ao território equatoriano. Os dados obtidos pela pesquisa indicaram que o local foi densamente ocupado e que, durante seu apogeu, havia uma organização social hierarquizada e com forte poder religioso. Essa sociedade entrou em declínio no Século XVI, quando iniciou a ocupação espanhola no local (Endere \& Zulaica, 2015, p. 265).

A ocupação efetiva por colonizadores europeus iniciou no século XIX. No ano de 1979, o Parque Nacional foi criado, alterando o modo de vida da população local, que vivia da exploração dos recursos naturais advindos da área em que foi implantado o parque. Com isso, a comunidade protestou, afirmando que ocupava o local desde 1930, reivindicando o direito de permanecer naquelas terras (Endere \& Zulaica, 2015, p. 265).

${ }^{6}$ Tradução dos autores para termo apresentado em língua inglesa National Plan for Good Living. 
A partir de 1978, pesquisas arqueológicas foram desenvolvidas com o envolvimento da comunidade, que, qualificada pelos pesquisadores, começou a trabalhar nas escavações arqueológicas, tanto em campo como em laboratório (Endere \& Zulaica, 2015, p. 265).

Com a melhora da relação entre comunidade e autoridades do parque, a pesquisa arqueológica potencializou a atração turística. Com o apoio financeiro de instituições externas, o projeto arqueológico-turístico consolidou-se no ano de 1990, quando foi aberto ao público o Museu Local da Comunidade de Agua Blanca (Endere \& Zulaica, 2015, p. 267).

No ano de 2005, auxiliada pelos dados produzidos com a pesquisa arqueológica, a comunidade foi reconhecida como Pueblo Manta, em virtude dos grupos pré-hispânicos que habitavam a região. A pesquisa arqueológica desenvolvida ao longo dos anos contribuiu para reforçar os laços culturais e a preservação in situ do patrimônio arqueológico, criando uma integração entre pesquisadores e comunidade (Endere \& Zulaica, 2015, p. 268).

Endere e Zulaica (2015, p. 279) consideram que "the socio-cultural sustainability of heritage sites reflecting the Good Living of the communities and their evaluation through indicators is a useful starting point for reversing critical situations". O envolvimento da comunidade na pesquisa arqueológica e consequentemente a identidade com o patri

\footnotetext{
${ }^{7} \mathrm{O}$ número de estudos arqueológicos tem aumentado exponencialmente desde a promulgação da Lei do Ambiente em 1994, que inclui a pesquisa arqueológica
}

mônio foram fundamentais para os resultados obtidos na avaliação. O autogerenciamento e o autofinanciamento são pontos fortes em Agua Blanca. Para o Bem Viver, é necessária a flexibilidade, que permite a autogestão sem comprometer a autonomia da comunidade, porém o envolvimento governamental é importante. Esse indicador não comprometeu a valorização e o desenvolvimento do turismo devido à sua autossuficiência. Desta forma, as autoras acreditam que a avaliação poderá contribuir para a melhora na sustentabilidade sociocultural do sítio, corroborando com o Bem Viver (Endere \& Zulaica, 2015, p. 279).

\subsection{Chile - San Pedro de Atacama}

No Chile, o turismo arqueológico se destaca em San Pedro de Atacama ao norte. Ayala (2015) apresentou a pesquisa arqueológica de contrato e sua atuação frente à população local. No caso de San Pedro de Atacama, verifica-se uma intensa atividade mineradora, que tem exigido muitos trabalhos e arqueologia de contrato ${ }^{7}$. Contudo, a relação dos pesquisadores com os grupos étnicos da região nem sempre foi harmoniosa. A região também é um dos principais destinos turísticos do Chile. Por estarem prestando serviços aos empreendimentos, pesquisadores de arqueologia não se envolvem nas discussões sobre os impactos socioambientais da mineração e do turismo na região, porém, frente ao avanço dessas atividades econômi-

no estudo de impacto ambiental, constituindo-se na principal atividade no Conselho (Ayala, 2015, p. 160). 
cas, as pesquisas desenvolvidas têm corroborado para a proteção do patrimônio cultural, ainda que pese o fato dos pesquisadores se omitirem diante das questões políticas (Ayala, 2015, p. 162).

O desenvolvimento da mineração atraiu investimentos para o turismo na região, inclusive para o museu de arqueologia de San Jose de Atacama, revitalizado recentemente. As pesquisas arqueológicas desenvolvidas possibilitaram que, no ano de 1983 , fosse realizado o primeiro Simpósio de Arqueologia do Atacama, no qual se discutiram a proteção e a conservação do patrimônio e sua relação com o turismo (Ayala, 2015, p. 163).

Ayala (2015, p. 164) relata ainda que a promulgação da Lei Indígena permitiu que os povos originários da região passassem a reivindicar questões de seu interesse, que não eram observadas anteriormente. Inicialmente, surgiram animosidades entre os grupos indígenas e os arqueólogos contratados por empresas. Os pesquisadores eram criticados por não contribuírem com a defesa dos grupos indígenas atuais. Por meio de reivindicações de populações atacamenhas, a comunidade local passou a ser inserida em projetos de desenvolvimento turístico e de educação patrimonial. Com a geração de renda motivada pelo turismo, ocorreu o retorno gradual da população indígena para suas comunidades de origem que foram beneficiadas financeiramente pelo movimento turístico e arqueológico. Os órgãos governamentais passaram a integrar os atacamenhos em iniciativas e projetos envolvendo o patrimônio arqueológico e a gestão do turismo em sítios arqueológicos. Ayala (2015, p. 165) afir- ma que "neste contexto, a arqueologia em Atacama ativou seu lado patrimonial para trabalhar com agentes do Estado e indígenas na incorporação de sítios arqueológicos para o mercado turístico".

Com a possibilidade de proteção do patrimônio arqueológico sob a ótica do turismo, arqueólogos passaram a envolver-se mais na avaliação de projetos e resolução de conflitos. Com a inserção do patrimônio no turismo e, consequentemente, sua valorização econômica, os sítios arqueológicos passaram a ser vistos como um legado a ser preservado. Ayala (2015, p. 170) reforça que os grupos indígenas da região de San Jose de Atacama "através da patrimonialização, questionam ao Estado multicultural a partir de dentro e participam nas novas lutas para a definição, classificação e apropriação de seu patrimônio".

O caso chileno demonstra a importância do envolvimento da população local na pesquisa arqueológica e a valorização econômica por meio do turismo responsável, que pode se converter na salvaguarda de sítios arqueológicos. A atividade turística produziu destaque ao patrimônio arqueológico local, beneficiando populações autóctones e gerando renda.

\subsection{Estados Unidos da América - Green Ta- ble National Park}

Nos Estados Unidos, um estudo de caso que se destaca é o do Green Table National Park, localizado no Colorado, onde estão cadastrados vários sítios arqueológicos dos ancestrais do Povo Pueblo, indígenas originários da região. Muitos desses sítios são 
abertos à visitação, mas o número de visitantes vem caindo com o passar do tempo (Walls \& Longo, 2005). Com a organização da celebração do centenário do parque, a Green Table Museum Association espera alavancar o número de visitantes e aumentar a renda do local. A expectativa do diretor executivo, Tracy Chavis, era mudar a realidade do Green Table por meio de um plano de marketing que estimularia o interesse das pessoas pelo parque.

O Green Table National Park tem uma área de aproximadamente 21.000 hectares, com mais de 4.400 sítios arqueológicos, dos quais cerca de 35 são passíveis de visitação. Segundo Walls e Longo (2005, p. 16), o parque é considerado um patrimônio cultural da humanidade, sendo o primeiro parque nos Estados Unidos credenciado para a proteção do patrimônio arqueológico. O visitante, por meio de visita guiada, pode conhecer e visitar os sítios arqueológicos, além de ter contato com um ambiente natural exuberante.

Ainda assim, todo o potencial cultural e ambiental não inibiu a queda no número de visitantes, que não foi exclusiva deste parque nos Estados Unidos. Os autores destacam que o Grand Canyon também seguiu a mesma tendência. Fatores como a alta do dólar, o preço dos combustíveis e ataques terroristas foram nominados como possíveis causas desse efeito. Outro fator teria sido o fato de o parque ter sido atingido pelo fogo, uma vez que os incêndios ocorreram em profusão no ano 2000. A baixa quantidade de visitas reduziu a arrecadação, agravando a situação financeira do parque.

\section{TURISMO E GESTÃO DO PATRIMÔNIO NO BRASIL}

\subsection{Nova Olinda, CE - Fundação Casa Grande}

No Brasil, inicia-se a digressão com o caso discutido por Veloso e Calvacante (2007), que tratam do caso da Fundação Casa Grande - Memorial Homem do Kariri, na cidade de Nova Olinda, Ceará, onde o turismo arqueológico foi desenvolvido sem excluir a comunidade local. A Fundação desenvolve projetos para qualificar jovens e adultos da região por meio de ações educativas em gestão cultural, museologia e arqueologia. Os integrantes aprendem a recepcionar e conduzir visitantes interessados em conhecer o patrimônio arqueológico regional, que tem um sítio arqueológico musealizado in situ. Ali, o visitante tem a possibilidade de conhecer e compreender mais sobre a ocupação do local. Um sistema de hospedagem domiciliar foi organizado por meio de uma cooperativa própria, gerando emprego e renda para as famílias. Os autores destacam que a região possui grande potencial para o turismo arqueológico.

\subsection{Saquarema, RJ - Sambaqui da Beirada}

No Estado do Rio de Janeiro, um projeto foi desenvolvido com o apoio de arqueólogos que atuavam no município de Saquarema. Trata-se do Museu Sítio Arqueológico do Sambaqui da Beirada. Como forma de aproximar a população do patrimônio arqueológico regional, foi criada a Praça do Samba- 
qui da Beirada, atualmente um local de visitação turística. A iniciativa desenvolvida pelos pesquisadores teve o interesse de buscar o apoio da população para a preservação e a proteção do patrimônio local.

O sambaqui musealizado possuiu uma área de $7.000 \mathrm{~m}^{2}$ e expõe in loco os vestígios arqueológicos deixados por grupos humanos pescadores-caçadores-coletores. No local, o visitante pode visualizar, entre outras evidências, vestígios de sepultamentos humanos, aspectos construtivos do sítio e alguns artefatos líticos. Entre as estratégias adotadas para o desenvolvimento da atividade no local, destacam-se o desenvolvimento da pesquisa arqueológica, a apresentação dos vestígios in situ como forma de apresentar a cultura aos visitantes, o cercamento do local e a proteção dos vestígios evidenciados, a área expositiva, a educação patrimonial para a comunidade local, o desenvolvimento de um plano de manejo e a implantação de infraestrutura de apoio para os visitantes. Essas estratégias foram adotadas a fim de contribuir para a proteção do patrimônio arqueológico local (Veloso \& Cavalcanti, 2007, p. 161).

\subsection{São Raimundo Nonato, PI - Serra da Capivara}

Um caso bastante emblemático no Brasil é a gestão do patrimônio arqueológico no Parque Nacional da Serra da Capivara, unidade de conservação criada a partir da solicitação ao Governo Federal pela equipe de cooperação científica franco-brasileira no ano de 1979. Possui uma área de 129.140 hectares, onde foram cadastrados mais de 1.000 sítios arqueológicos (700 são de arte rupestre). Além disso, foram mapeados acampamentos ligados aos grupos caçadores-coletores, aldeias ceramistas, ocupações de abrigos e grutas, sítios funerários e sítios paleontológicos (Buco, 2012; Guidon, 2007).

A equipe de pesquisa buscou, com a proposta de criação do parque, alternativa para aumentar a proteção dos sítios arqueológicos da região, ameaçados constantemente por ocupações irregulares e desmatamento contínuo. O parque intercepta a área de quatro municípios: São Raimundo Nonato, João Costa, Brejo do Piauí e Coronel José Dias, todos no Estado do Piauí.

As pesquisas arqueológicas são realizadas na região desde a década de 1960 por meio de cooperações nacionais e internacionais. A importância de seus sítios arqueológicos permitiu que o parque fosse inscrito pela UNESCO na lista do Patrimônio Cultural Mundial no ano de 1991. Em nível nacional, o registro no livro do Tombo Arqueológico, Etnográfico e Paisagístico como Patrimônio Nacional foi realizado no ano de 1993 pelo IPHAN (Buco, 2012; Guidon, 2007; Veloso \& Cavalcanti, 2007).

A gestão do parque é realizada por meio da parceria entre um órgão governamental, o Instituto Brasileiro do Meio Ambiente e dos Recursos Naturais Renováveis (IBAMA) e a Fundação Museu do Homem Americano (FUMDHAM), organização da sociedade civil de interesse público. A FUMDHAM mantém uma parceria com o IPHAN para as questões referentes à conservação e à defesa do patrimônio arqueológico regional (Guidon, 2007, p. 75).

Para além de uma unidade de conser- 
vação, a Serra da Capivara é fundamentalmente um parque arqueológico. O plano de manejo estabelece a necessidade de preservar e manter o equilíbrio ecológico, tendo em vista o restabelecimento das relações harmoniosas entre patrimônio cultural, meio ambiente e população local (Buco, 2012, p. 93). Segundo Guidon (2007, p. 87), desde o princípio se pensou em criar uma estrutura que fosse autossustentável. Por meio de auxílio de instituições internacionais, foram realizados estudos com o propósito de identificar atividades econômicas viáveis para a região. O turismo foi apontado pelo estudo técnico como a única possibilidade de atingir o desenvolvimento regional de forma ampla, aliando benefícios às comunidades locais e à preservação do patrimônio.

Uma série de obras de infraestrutura foi planejada para permitir a visitação aos sítios arqueológicos do parque, comportando estruturas de acesso, elementos informativos e de proteção. As visitas são guiadas por trilhas com diferentes graus de dificuldades. Alguns sítios foram adequados, permitindo o acesso de pessoas com dificuldade de locomoção. O deslocamento dentro do parque pode ser feito de carro e por isso áreas de estacionamentos foram instaladas no percurso. Alguns sítios estão próximos à rodovia, mas outros são mais distantes, obrigando a seguir trilhas abertas na vegetação. O parque conta com uma base de recepção e apoio ao visitante. Buco (2012, p. 100) reforça que "a visitação permanente tem demostrando que a movimentação de pessoas, guardas, visitantes e guias, inibem a entrada de pessoas mal intencionadas".

A sede da FUMDHAM fica localizada no município de São Raimundo Nonato e conta com o Museu do Homem Americano, o Centro Cultural Sérgio Motta, biblioteca, laboratórios e reserva técnica. Reúne informações e acervo dos vestígios arqueológicos encontrados nas pesquisas desenvolvidas em quase quatro décadas de investigação (Buco, 2012, p. 95).

Para ampliar a conservação dos sítios do parque, foram qualificados técnicos para atuarem na salvaguarda do patrimônio ameaçado. Devido aos riscos ambientais, um diagnóstico foi realizado, definindo as ações a serem tomadas e o monitoramento para evitar a reincidência. Estes riscos podem ser de ordem natural ou antrópica. A presença desses profissionais é essencial para a manutenção da conservação e da readequação da gestão frente a agentes perturbadores (Buco, 2012).

Durante a fase de implementação das trilhas para a visitação turística foram realizados estudos prévios da topografia, da pedologia e da análise florística, a fim de estabelecer os melhores trajetos. A partir disso, determinaram-se locais e materiais adequados para cada espaço. A implementação das infraestruturas foi acompanhada por arqueólogos para evitar possíveis danos ao sítio arqueológico (Buco, 2012, p. 97).

Vislumbrando a região como um polo turístico, percebeu-se a necessidade de qualificar a população, com destaque para a educação básica, considerada inexistente nas comunidades circunvizinhas ao parque. Nos primeiros anos ocorreu um intenso trabalho voltado para a formação básica e para a qualificação de professores. O trabalho ainda gerou a construção de cinco escolas nos arredo- 
res do parque, as quais atendiam mais de mil crianças em período integral. Com a impossibilidade financeira da FUMDHAM manter o programa, as prefeituras municipais deram continuidade, mas o processo de qualificação desenvolvido por mais de uma década foi interrompido, gerando a desativação de quatro das cinco escolas construídas (Guidon, 2007).

Atualmente, são desenvolvidas atividades educativas, porém o número de envolvidos reduziu drasticamente (170 crianças e 40 adolescentes atendidos no Centro de Artes de São Raimundo Nonato). As crianças e os adolescentes atendidos participam de atividades de arte, música, desenho, pintura, arte em argila e sementes e capoeira. Estas ações são realizadas pelo Programa Pró-arte, que propõe a integração artística e social com o meio ambiente, objetivando estabelecer a identidade com a população (Buco, 2012 , p. 98). O programa permite a qualificação de jovens aptos a trabalharem como técnicos nas escavações, nas prospecções arqueológicas, na conservação de sítios e nos estudos em laboratório. A FUMDHAM assegura também a formação dos guias de turismo que atuam no parque (Guidon, 2007).

Veloso e Cavalcante (2007) identificaram as seguintes estratégias de gestão no parque: criação da FUMDHAN; parcerias entre FUMDHAM, IPHAN e IBAMA; parcerias e convênios internacionais; desenvolvimento de estruturas para a visitação pública, museu, centro de visitantes, entre outras; estruturas de segurança; circuitos de visitação devidamente sinalizados; acessibilidade aos sítios; espaço para realização de eventos; serviço de guias locais; planos estratégicos para médio e longo prazo; programas de preservação e desenvolvimento econômico e social voltados para a comunidade.

O Parque Nacional da Serra da Capivara é o resultado da ação persistente de pesquisadores que atuam na região, principalmente Niède Guidon. A pesquisadora atua há décadas pela preservação dos sítios e pelo desenvolvimento do turismo como forma de atrair mais renda. A região ainda carece de infraestruturas viárias e de transporte. Dessa forma, sem o envolvimento efetivo do poder público no desenvolvimento regional, o patrimônio arqueológico não tem a visibilidade desejada, deixando uma lacuna no processo.

\subsection{Florianópolis, SC - Ilha do Campeche}

No Estado de Santa Catarina, Chamas e Schmidt (2011) descrevem o estudo de caso do desenvolvimento da atividade turística na Ilha do Campeche, localizada a 1,4 km da Praia do Campeche, na costa sudeste da Ilha de Santa Catarina, em Florianópolis. O estudo apresenta a gestão da ilha e como se desenvolveu o turismo no local, bem como a forma de organização.

Além de patrimônio natural, a ilha apresenta, integrada à sua paisagem, um conjunto de sítios arqueológicos. A paisagem natural da ilha é composta por vegetação de restinga e pioneira de costão rochoso, com a formação de cursos d'água intermitentes. Com exceção da praia, que mede aproximadamente 400 metros de extensão, todo o restante da ilha é circundado por um costão rochoso de diabásio e granito, no qual ocorrem diversos petroglifos e polidores, vestí- 
gios arqueológicos testemunhos de grupos pré-coloniais que ocuparam o local.

Sobre as ocupações na região, o estudo indica que os primeiros grupos humanos registrados viveram ali há 3000 anos a.C., constituídos por povos pescadores-caçadores-coletores e construtores de sambaquis. Por volta de 910 anos d.C., os grupos portadores da Tradição Itararé, pertencentes ao tronco-linguístico Macro-Jê, ocuparam a região. Mais recentemente, há cerca de 1300 anos d.C., ceramistas portadores da tradição Tupiguarani chegaram à região em período próximo à data da chegada dos colonizadores. Entre os grupos apresentados, apenas os dois últimos tiveram contado com os colonizadores (Chamas, 2008). De acordo com as informações do Cadastro Nacional de Sítios Arqueológicos (CNSA) do IPHAN, as evidências deixadas por ocupações pré-coloniais na ilha são: petroglifos, representações rupestres feitas a partir de incisões na rocha; oficinas líticas, que são áreas de produção artefatual; e um sítio com conchas.

Há registro de um sítio histórico, que segundo o cadastro do IPHAN é uma armação baleira do século XVIII, localizada junto à praia, cujas ruínas podem ser encontradas na praia. Chamas (2008, p. 51) descreve que essas edificações eram utilizadas, basicamente, para armazenar óleo de baleia.

Com o declínio da armação, a ilha passou a ser ocupada por pescadores artesanais, atraídos pela diversidade e pela quantidade de peixes. Embora os pescadores permanecessem por longos períodos, essa ocupação era sazonal. Ali construíam algumas edificações, como os ranchos de pesca, favorecendo o desenvolvimento da atividade no local até meados do século XX. Também foram registradas áreas de cultivo de alimentos, de uso comum pelos pescadores que utilizavam o local (Chamas, 2008).

No início da segunda metade do século $X X$, chegaram ao local os membros da associação do Clube de Caça, Pesca e Tiro Couto de Magalhães. Nesse período houve uma disputa pelo uso e ocupação da ilha. $\mathrm{O}$ desfecho foi a saída dos pescadores e a permanência do novo grupo. Com isso, novas estruturas foram construídas para permitir a permanência do grupo na ilha, onde foram também introduzidos animais domésticos e fauna exótica para se tornarem objetos de caça. Um exemplo disso são os quatis (Nasua nasua). Sem um predador natural, multiplicaram-se absurdamente, causando um desequilibro ecológico no local (Chamas, 2008). A Couto Magalhães (atualmente denominada Associação Couto de Magalhães de Preservação da llha do Campeche - ACOMPECHE) e a Pesqueira Pioneira da Costa S/A possuem a ocupação formalizada (Chamas, 2008, p. 56).

A partir da década de 1950, quando a ilha passa a ser utilizada para recreação e lazer, fato intensificado a partir da década de 1980, inicia também a preocupação com o conjunto de sítios arqueológicos do local. Com o vislumbre da ilha como atrativo turístico, a atividade ocorria sem planejamento e monitoramento dos impactos ao meio. Visando à proteção da Ilha do Campeche, no ano de 2000 houve o registro da localidade junto ao IPHAN como patrimônio arqueológico e paisagístico natural nacional.

A partir do reconhecimento pelo IPHAN, o mesmo órgão, em parceria com ou tros órgãos públicos e com os atores envolvi- 
dos, passou a ordenar o uso e a ocupação do local por meio de ações participativas, buscando a mediação dos conflitos e das tensões (Chamas \& Schmidt, 2011).

O registro como patrimônio não impediu que os integrantes do Clube Couto Magalhães continuassem exercendo suas atividades no local, uma vez que o direito de uso da propriedade não foi alterado. Contudo, foram criadas regras restritivas e até mesmo impeditivas para atividades que colocassem em risco o meio ambiente e os sítios arqueológicos. Foram realizadas ações de sensibilização e formação profissional entre os grupos envolvidos para readequação à nova realidade (Chamas \& Schmidt, 2011, p. 235).

Chamas e Schimdt (2011) relatam o desenvolvimento da atividade turística na perspectiva do ecoturismo, resultante de seminários e reuniões preparatórias, a fim de organizar um sistema de gestão público-privada para o estabelecimento de acordos para readequar o uso do espaço. Grupos da sociedade civil ligados à Ilha do Campeche participaram desta gestão, juntamente com o IPHAN (o representante governamental gestor), Polícia Ambiental (o órgão fiscalizador) e Ministério Público Federal - MPF (que fiscaliza a aplicação da lei).

As trilhas utilizadas nas visitas foram adequadas a partir de caminhos existentes, abertos pelos antigos usuários. Alguns trechos tiveram que ser interrompidos para conter processos erosivos do terreno e outros receberam degraus e decks, acompanhando a topografia do local. Visando garantir a integridade e reduzir os impactos ao meio, um estudo de capacidade de carga foi realizado para determinar o limite diário de pessoas na ilha. Chamas \& Schmidt (2011) avaliaram a área disponível para visitação, os fatores restritivos (como infraestrutura suficiente), as características dos visitantes e o tempo de permanência. Este estudo chegou ao coeficiente máximo de 770 visitantes diários (Chamas \& Schmidt, 2011).

A regulação de uso e de gerenciamento da ilha foi estabelecida pela Portaria do IPHAN no 621, de novembro de 2009, que norteia o monitoramento e apresenta o zoneamento da ilha, determinado a partir da análise de diversos fatores, prevendo a manutenção das construções e as demais benfeitorias realizadas pelo Clube. Quanto ao monitoramento, foram estabelecidas duas linhas de atuação: 1) monitoramento articulado com os trabalhos de sensibilização (em casos mais graves, aplicam-se sanções); e 2) organização das informações para avaliação da gestão e da produção científica (Chamas \& Schmidt, 2011, p. 236).

A gestão da ilha apresenta diversos aspectos positivos, como o desenvolvimento de atividades educativas e qualificação de monitores para a visitação guiada ao local, principalmente na alta temporada, entre novembro e março.

Anualmente, é organizado um curso para os monitores da Ilha do Campeche, aberto para a comunidade em geral. Parte dos alunos qualificados pelo curso é integrada à equipe de monitores durante a temporada de verão.

Os monitores desenvolvem funções que vão desde o local de embarque de visitantes para a ilha, informações para os visitantes, controle de entrada de pessoas, monitoramento, acompanhamento em trilhas, 
entre outras. Os circuitos de trilhas terrestres têm uma duração aproximada de uma hora, com diferentes graus de dificuldade. Com extensão de até 800 metros, as trilhas comportam grupos de até 16 pessoas, acompanhados por dois monitores. Os atrativos das triIhas são os elementos culturais e naturais que compõem a paisagem. As trilhas subaquáticas são desenvolvidas em dois pontos da ilha, um ao norte e outro ao sul. As trilhas desenvolvidas com até 12 participantes possuem uma proporção de 1 monitor para cada 4 visitantes. Um barco leva o grupo até o ponto e os aguarda até o enceramento da atividade (Chamas \& Schmidt, 2011).

Chamas e Schimdt (2011) reforçam que o sistema de monitoramento foi sendo aperfeiçoado. Em seu início, tinham como base reuniões e seminários realizados, inclusive, pela equipe de monitores. Gradualmente, os relatórios foram se tornando mais informativos, com dados numéricos referentes à visitação. Os conflitos e os pontos de tensão foram sendo resolvidos e amenizados. Antes mesmo do embarque, o visitante recebe informação sobre as atividades desenvolvidas e as restrições estabelecidas. Todas as manhãs a equipe de gestão faz avaliação e informa aos agentes turísticos sobre as condições de visita para o dia.

Como forma de amenizar o conflito com esses atores, buscou-se sensibilizá-los sobre a fragilidade da ilha por meio da realização de seminários (Chamas \& Schmidt, 2011, p. 238).

O estudo de capacidade de carga da ilha foi um ponto fundamental para a preservação do patrimônio natural e cultural. 0 controle e o monitoramento da atividade turística e outros usos são realizados por meio de registros em relatórios, que subsidiam desde a determinação da equipe de monitores necessários e até auxiliam na aplicação de sanções pelo mau uso da ilha.

Como já mencionado, o ordenamento do uso da Ilha do Campeche ocorre com a condução do governo federal e a participação da sociedade civil, parceria que tem garantido a salvaguarda do patrimônio. Chamas e Schimdt (2011, p. 241) informam que houve três elementos fundamentais: "conscientização pública, estabelecimento de regulamento e monitoramento" ${ }^{\prime 8}$.

Tendo em vista o cenário brasileiro, Veloso e Cavalcante (2007) destacam que o turismo arqueológico vem ganhando espaço nos últimos anos. Embora pouco difundido no Brasil, o país deveria observar os casos de sucesso e espelhar-se para estimular o crescimento. Veloso e Cavalcante (2007) consideram que o turismo arqueológico pode ser fonte para o desenvolvimento socioeconômico e a cidadania cultural para as comunidades receptoras.

O Brasil possui grande potencial para o desenvolvimento do turismo arqueológico, tendo em vista a quantidade e a diversidade do patrimônio. A interação entre patrimônio arqueológico e turismo deve ser antecedida por uma organização meticulosa, com ações concretas que visem à salvaguarda desses bens frágeis e não renováveis.

\footnotetext{
${ }^{8}$ Tradução dos autores para: "public awareness, the establishment of regulations and monitoring".
} 


\section{GESTÃO DO TURISMO E DO PATRIMÔNIO ARQUEOLÓGICO}

A elaboração de políticas públicas que possam garantir benefícios para a maior parcela da sociedade é uma busca constante, seja por parte do Estado, seja por parte de lideranças empresariais e da sociedade civil organizada. Segundo Oliveira \& Pisa (2015, p.1264-65):

Políticas públicas devem ser compreendidas como aquelas ações que um determinado governo escolhe implementar com o objetivo de atender a uma demanda pública ou resolver um problema, lembran-do-se que essa escolha sofre forte influência política em função dos interesses dos diversos setores que podem por ela ser beneficiados.

Quando essas políticas atingem a participação dos demais atores da sociedade, há a busca de um consenso na definição dos objetivos voltados para a obtenção de resultados benéficos a todos os participantes. $O$ estímulo para que a sociedade civil organizada participe no processo de gestão pública permite a busca pelo desenvolvimento, respeitando a vontade da população (Hall, 2011).

A atividade turística tem sido uma alternativa para diversos locais ao redor do mundo repensar o seu desenvolvimento econômico e a sustentabilidade ambiental, social e cultural. Tradicionalmente, o papel do turismo tem sido reconhecido como um instrumento de desenvolvimento endógeno com potencial de gerar riqueza e emprego. Uma das circunstâncias essenciais é a governança ou a gestão do destino, ou seja, coordenação, colaboração e/ou cooperação entre os dife- rentes atores envolvidos no processo de desenvolvimento turístico, de forma a garantir o efeito multiplicador do turismo na economia local (Pulipo Fernandez \& Pulipo Fernandez, 2017).

O processo de gestão de uma localidade turística varia de acordo com as peculiaridades regionais, a participação de seus atores em diversos níveis (Zahra, 2011), entre outros aspectos relevantes. Nesse sentido, o conceito de governança também vem ganhando força no processo de gestão do turismo. $O$ estudo da governança já vem sendo utilizado como um conceito de pesquisa em turismo desde 1993 (Wang \& Li, 2013). Segundo Hall (2011, p.437), "governança é um conceito chave na política e em políticas públicas e tem sido utilizado com maior frequência no turismo".

A necessidade de o turismo competir num mercado global e cada vez mais acirrado faz com que o processo de governança desta atividade busque a competitividade do destino, maximizando as mudanças necessárias para se chegar neste estágio. Conforme Seixas \& Mas (2010, p. 8):

Muitos dos novos tipos de governança vêm da intenção e necessidade de acelerar a competitividade, em termos de transformações estruturais e crescimento econômico urbano, onde a cidade é considerada um agente coletivo que deve buscar recursos que são escassos (como investimentos econômicos, imagem, turistas, arquitetura espetacular) para garantir um lugar vantajoso no mercado urbano.

Sendo o turismo uma atividade que afeta diretamente não só a economia de um local, mas também o meio de vida de sua população, o processo de governança deve ga- 
rantir a inclusão dos mais variados atores, como as comunidades, os governos e o trade turístico. Assim possibilitará maior coesão na gestão e, possivelmente, maior relevância mercadológica para o destino (Zahra, 2011).

Para a utilização do patrimônio arqueológico como atrativo turístico, é de fundamental importância o planejamento e a gestão da atividade. Sendo um ambiente frágil, o impacto gerado ao meio deverá ser minimizado para não se colocar em risco o próprio patrimônio.

Em se tratando de patrimônio arqueológico, uma série de cartas, declarações e normas, entre outras recomendações oriundas de discussões em várias partes do mundo e promovidas por entidades como a União das Nações Unidas pela Educação e Cultura (UNESCO), Organização dos Estados Americanos (OEA), Conselho Internacional dos Monumentos e Sítios (ICOMOS), constituem a base para uma gestão sustentável.

No ano de 1962, em Paris, na conferência geral da UNESCO, elaboraram-se recomendações para a salvaguarda da beleza e do caráter das paisagens e dos sítios. $O$ texto relativo às medidas de salvaguarda afirma que ela deverá ser assegurada com o auxílio dos seguintes métodos:

a) Controle geral por parte das autoridades competentes;

b) Inserção de restrições nos planos de urbanização e no planejamento em todos os níveis: regional, rural ou urbano;

c) Proteção legal, "por zonas", das paisagens;

d) Proteção legal dos sítios isolados;

e) Criação e manutenção de reservas naturais e parques nacionais; f) Aquisição de sítios pelas coletividades públicas" (Unesco, 1962).

O documento enfatiza a importância da educação patrimonial, com ação educativa desenvolvida, "dentro e fora das escolas, para despertar e desenvolver o respeito do público pelas paisagens e sítios e para tornar mais conhecidas as normas editadas para garantir sua salvaguarda" (Unesco, 1962). Fala ainda da importância da preparação do educador, que deverá ser específica, focada na temática. Enfatiza também a educação do público fora da escola. O documento orienta para um trabalho de sensibilização do público em geral que "deveria ser tarefa da imprensa, das associações privadas de proteção das paisagens e dos sítios ou de proteção da natureza, dos órgãos encarregados do turismo e das organizações de juventude e educação popular" (Unesco, 1962).

Em maio de 1964, no encontro do ICOMOS, formulou-se um documento chamado Carta de Veneza, que define monumentos como:

Portadores de mensagem espiritual do passado, as obras monumentais de cada povo perduram no presente como o testemunho vivo das suas tradições seculares. A humanidade, cada vez mais consciente da unidade dos valores humanos, as considera um patrimônio comum e, perante as gerações futuras, se reconhece solidariamente responsável por preservá-las, impondo a si mesma o dever de transmiti-las na plenitude de sua autenticidade (Icomos, 1964).

O mesmo documento, em seu Artigo 14 , versa sobre a preservação dos sítios monumentais e afirma que "devem ser objeto de cuidados especiais que visem a salvaguar- 
dar sua integridade e assegurar seu saneamento, sua manutenção e valorização" (Icomos, 1964).

Em seu encontro no ano de 1967, a OEA apresentou o que ficou reconhecido como Normas de Quito, em uma reunião sobre conservação e utilização de monumentos e sítios de interesse histórico e artístico. O documento destaca a importância da preservação do patrimônio e a sua valorização econômica.

A Europa deve ao turismo, direta e indiretamente, a salvaguarda de uma grande parte de seu patrimônio cultural, condenado à completa e irremediável destruição, e a sensibilização contemporânea, mais visual que literária, tem oportunidade de se enriquecer com a contemplação de novos exemplos da civilização ocidental, resgatados tecnicamente graças ao poderoso estímulo turístico (OEA, 1967).

Em 1990, foi apresentada a Carta de Lausanne, cujo foco foi a proteção e a gestão do patrimônio arqueológico, enfatizando que esse monumento é um recurso frágil e, sobretudo, não renovável, destacando que "Os planos de ocupação do solo decorrentes de projetos desenvolvimentistas devem, em consequência, ser regulamentados, a fim de minimizar, o mais possível, a destruição desse patrimônio" (Icomos/Icahm, 1990). Segundo a carta, o monumento arqueológico é um bem de todos e é obrigação moral de todo ser humano protegê-lo. Aos países, cabe assegurar e disponibilizar recursos financeiros suficientes para a sua proteção (Icomos/Icahm, 1990). O desenvolvimento desordenado ainda configura grande ameaça à preservação do patrimônio arqueológico.
Cabe ao poder público estimular o desenvolvimento de maneira planejada para não comprometer o patrimônio cultural e natural. "A proteção do patrimônio arqueológico constitui processo dinâmico permanente. Por conseguinte, todas as facilidades devem ser concedidas aos profissionais trabalhando nessa área, a fim de permitir sua permanente reciclagem" (Icomos/Icahm, 1990).

Na IX Assembleia Geral do ICOMOS, em 9 de outubro de 1996, foi redigida a Declaração de Sófia, que indica que o processo de desenvolvimento do turismo cultural deverá garantir a participação da sociedade civil, juntamente com ações das autoridades políticas e administrativas, primando pela preservação e pelo desenvolvimento sustentável dos recursos culturais e naturais (Icomos, 1996).

As atividades turísticas, por outro lado, não podem pretender utilizar o patrimônio assegurando apenas o respeito ao significado e à sua mensagem. Para que esta fruição seja viável e válida, serão necessários sempre estudos analíticos e inventários completos, com o objetivo de explicar os diversos significados do patrimônio no mundo contemporâneo e justificar as novas modalidades de uso a que se propõem (...). E, sem dúvida, antes de as atividades turísticas serem supervalorizadas, arriscando-se a transformá-la em ameaça à integridade das substâncias do patrimônio cultural, levar-se-á em conta, e cada vez mais, a relação e a comunidade que o herdou. Convém acrescer que esta relação integra o conjunto dos elementos históricos, espirituais e afetivos existentes na raiz das transformações sociais (Icomos, 1996). 
Estas discussões, construídas ao longo de décadas, contribuíram para consolidação de políticas públicas para a salvaguarda e valorização do patrimônio cultural, dentre eles, os reminiscentes materiais, os sítios arqueológicos e, ainda, o aproveitamento no turismo.

\section{PROCESSOS PARA GESTÃO DO TURISMO ARQUEOLÓGICO}

Nas práticas patrimoniais apresentadas nos estudos de casos nacionais e estrangeiros, percebeu-se um forte apelo para a participação popular, as políticas públicas, as parcerias público-privadas, a educação patrimonial, o reconhecimento do potencial turístico-arqueológico e a avaliação e o monitoramento de destinos turísticos arqueológicos.

A emergência destas dimensões em casos mundiais permite indicar direções mais seguras para a gestão de destinos que possuam tais características. Desta forma, emerge uma proposição de um processo de gestão de destinos que cumpra garantir a proteção do patrimônio e, ao mesmo tempo, que permita o desenvolvimento da atividade turística. Dos referenciais apresentados, emergiram cinco dimensões, as quais serão denominadas de: Educação Patrimonial; Reconhecimento do Potencial Turístico-Arqueológico; Políticas Públicas, Programas e Parcerias Público-Privadas; Promoção e Divulgação dos Atrativos Turístico-Arqueológico; e Monitoramento e Avaliação.

\subsection{Educação Patrimonial}

O desenvolvimento do turismo que envolve o patrimônio arqueológico exige o envolvimento da população, fomentado por ações educativas para a valorização do patrimônio local e, ainda, sua participação no desenvolvimento de programas para a gestão do patrimônio cultural. Nos estudos de casos apresentados, sempre que a comunidade local esteve atuante, o resultado foi um progressivo aumento da valorização e da identidade com o patrimônio, que consequentemente possibilitou a sua preservação. Com isso, a comunidade local tornou-se porta-voz de seu legado cultural.

As comunidades circunvizinhas aos sítios arqueológicos poderão ser importantes aliadas na proteção do patrimônio arqueológico; interação que Veloso e Cavalcante (2007) e Ayala (2015) destacaram em suas pesquisas. Ayala (2015) demonstrou, em seu estudo, que, inicialmente, a comunidade não foi envolvida no desenvolvimento de atividades relacionadas ao patrimônio arqueológico. Havia, segundo ela, certa antipatia entre os pesquisadores e a população local. Porém, a comunidade começa a ser integrada em projetos de arqueologia e na gestão do turismo, sendo beneficiada diretamente. Com isso, constatou-se um maior envolvimento com o patrimônio local.

Um exemplo dessa integração da comunidade foi o caso apresentado por Griffith e Griffith (2012), quando a população local teve um importante papel na viabilização da atividade, sendo integrada à gestão do patrimônio e ao desenvolvimento do turismo. A população foi qualificada, visando à valorização do patrimônio e fortalecendo da identidade, tornando-a capaz de divulgar uma história própria, sem a necessidade de uma atu- 
ação contínua de especialistas. Os problemas identificados eram solucionados por meio de iniciativas participativas, trabalhando com stakeholders, discutindo soluções para conservar e preservar o patrimônio, para reverter o avanço do turismo desordenado.

No Equador, Endere e Zulaica (2015) expõem um modelo de desenvolvimento com forte participação da população no desenvolvimento da atividade turística e na preservação do patrimônio. Esta realidade garantiu a permanência da população no local e, ainda, possibilitou o retorno de indivíduos que partiram em busca de melhores condições de vida. As autoras destacam dois pontos fortes no modelo apresentado, o autogerenciamento e o autofinanciamento, que permitiram a autonomia da comunidade.

Visando à integração e à sensibilização dos diversos atores para a valorização e preservação do patrimônio arqueológico, ações educativas foram destacadas por Walls e Longo (2005), Guidon (2007), Veloso e Cavalcante (2007), Chamas e Schmidt (2011), Buco (2012), Griffith e Griffith (2012), Ayala (2015) e Endere e Zulaica (2015). A Educação Patrimonial tem por objetivo sensibilizar para a preservação do patrimônio cultural, e é uma ação que deverá ser desenvolvida de forma processual, por meio de metodologias educativas, que busquem difundir, valorizar e preservar o patrimônio local. Além disso, as ações poderão ser desenvolvidas buscando a qualificação para o turismo arqueológico.

A participação da comunidade local é de fundamental importância para a obtenção de resultados positivos no processo de planejamento do Turismo Arqueológico. Nas pesquisas que apresentaram a forma de partici- pação da comunidade, houve a valorização e a preservação, e a identificação com o patrimônio local foi efetiva. Um trabalho educativo desenvolvido de forma processual será de fundamental importância para garantir a proteção do patrimônio, elaborada para a comunidade escolar, população em geral, trade turístico e organismos governamentais.

\subsection{Reconhecimento do Potencial Turístico- Arqueológico}

Villalobos (2014), em seu estudo, evidencia a importância do desenvolvimento de uma pesquisa arqueológica mais equânime, tendo em vista a supervalorização dada a algumas tipologias de sítios arqueológicos, especialmente os monumentais. Sítios imponentes integrados ao discurso ideológico nacionalista são facilmente supervalorizados, e da mesma maneira foram e continuam sendo apropriados pela atividade turística, enquanto a diversidade de sítios existentes, muitas vezes, é desconsiderada, sendo os não monumentais relegados.

Sugiura e Nieto (2014) destacam que os próprios arqueólogos manifestam mais interesse pelos sítios monumentais. Sítios arqueológicos com dimensões menores, porém representativos, se tornam vulneráveis aos processos de destruição, principalmente pelo desenvolvimento urbano. Sugiura e Nieto (2014) analisam a realidade do patrimônio arqueológico mexicano, descrevendo que sítios arqueológicos, no país, muitas vezes são vistos como entrave ao desenvolvimento. Esta é também uma realidade constatada no Brasil.

A destruição de sítios de pequeno 
porte poderá inviabilizar o entendimento sobre ocupação humana, impossibilitando que lacunas na pesquisa sejam ultrapassadas. Conforme reforçaram Sugiura e Nieto (2014) e Villalobos (2014), o levantamento arqueológico contribuirá para a compreensão da cronologia de ocupação, diversidade e quantidade de sítios arqueológicos presentes na área de pesquisa e, com isso, espera-se que os demais sítios, não aproveitados pelo turismo, sejam salvaguardados.

Estudos como o de Guidon (2007) e Chamas e Schmidt (2011) destacaram a determinação da capacidade de carga como forma de possibilitar o uso turístico de sítios arqueológicos e garantir a salvaguarda do patrimônio.

Em se tratando da viabilidade da atividade, o turismo concebido a partir de um planejamento responsável poderá trazer uma série de benefícios. Conforme Copeta e Giacome (2010) reforçam, o desenvolvimento econômico e sociocultural pode ser viabilizado pela atividade, com isso beneficiando diretamente o patrimônio e as comunidades locais.

$\mathrm{Na}$ Turquia, algumas medidas foram adotadas a fim de garantir a otimização de geração de renda no país, com a terceirização das lojas de presentes. Os produtos, obrigatóriamente, deveriam ser artesanatos de fabricação nacional e que tivessem relação com o patrimônio visitado. Porém, o modelo de gestão do patrimônio cultural adotado pelo governo turco, conforme exposto por Shoup et al. (2014), foi implantado de forma verticalizada, sendo criticado pelos autores pela baixa participação popular e pelo mono- pólio de serviços. A atividade turística envolvendo o patrimônio cultural deverá ser concebida com a participação integrada da comunidade local.

\subsection{Políticas Públicas, Programas e Parcerias Público-Privadas}

Frente ao desenvolvimento da atividade turística, a proteção do patrimônio arqueológico é primordial. Os estudos analisados indicaram a importância da elaboração de políticas públicas para garantir a salvaguarda do patrimônio. Juárez (2002), Guidon (2007), Chamas e Schmidt (2011), Buco (2012) e Chivu (2013) desvelam que a utilização do legado arqueológico pela atividade turística poderá valorizar o patrimônio, desde que: seja realizado o registro desses bens; estes possam contar com uma legislação e documentos que orientem o uso, considerando suas especificidades; e ainda, sejam desenvolvidas iniciativas para sua valorização.

A musealização do patrimônio para visitação é de fundamental importância, tanto para deixá-lo mais atrativo, quanto para protegê-lo de eventuais danos. Guidon (2007), Chamas e Schmidt (2011), Buco (2012) e Endere e Zulaica (2015) apresentam em seus estudos as infraestruturas criadas, a fim de possibilitar a visitação de sítios arqueológicos. Trata-se de trilhas, estruturas de proteção, placas informativas, entre outras. A musealização, para além de um espaço preparado para o visitante, conforme enfatiza Veloso e Cavalcante (2007), é um meio de aproximar a comunidade local ao patrimônio. 
A salvaguarda de sítios arqueológicos vem sendo negligenciada em várias partes do mundo, e registros de pilhagem ainda são observados, sendo fomentados principalmente pelo comércio ilegal. A utilização do patrimônio de maneira inadequada, a incompreensão na proteção e a própria fragilidade poderá acarretar a destruição. Independentemente de sua utilização, numa perspectiva de gestão do patrimônio, é necessário um plano de manejo e conservação, visando à determinação de ações que venham salvaguardar monumentos arqueológicos.

Tendo em vista a preservação da originalidade do patrimônio, conforme destacou Chivu (2013), é importante a participação de especialistas nos processos de conservação. Ainda que motivados para a intenção de proteção, intervenções realizadas sem a participação de especialistas podem descaracterizar o patrimônio. Griffith e Griffith (2012) enfatizaram que intervenções sem a participação de especificidades pode ser danosa, pondo em risco os bens. No caso apresentado pelos autores, foi possível conter a destruição por meio de um plano de manejo e conservação condizente com as exigências do sítio arqueológico. Conforme Ramírez et al. (2010), a adoção de medidas preventivas e a adequação dos espaços poderão garantir a conservação do patrimônio, e estes reforçam ainda que é imprescindível a integração da população local no processo de gestão, buscando promover uma aproximação com os bens arqueológicos. Chavarría (2012) e Villalobos (2014), corroborando com a ideia de Ramírez et al. (2010), enfatizam a importância de se elaborar um plano de manejo para os sítios arqueológicos. Buco (2012) destaca que o plano de manejo estabelece a necessidade de preservar e manter o equilíbrio das relações entre patrimônio cultural, meio ambiente e população local.

O estabelecimento de parcerias entre os setores público e privado poderá contribuir para a viabilização da atividade (Copeta; Giacomo, 2010; Chamas; Schmidt, 2011). Um dos estudos mais contundentes sobre iniciativas de parcerias públicas e privadas foi o caso da Turquia. Frente às dificuldades administrativas encontradas e a baixa qualidade na prestação de serviços aos visitantes, novas estratégias visando à participação da iniciativa privada e a modernização dos espaços foram adotadas. Shoup et al. (2014) apresentaram o modelo de terceirização adotado para os serviços comerciais desenvolvidos em monumentos e museus. O modelo permite a participação de empresas privadas na gestão do patrimônio cultural, porém as decisões permanecem centralizadas no poder público. Na Turquia, a terceirização permitiu um maior controle na venda de ingressos, contribuindo para o aumento na receita. Outro fator importante foi a modernização da gestão e o acompanhamento da venda de ingressos em tempo real.

A manutenção da atividade envolvendo o turismo e o patrimônio arqueológico requer a busca por diferentes formas de fomento. Com a escassez de recursos para o desenvolvimento de propostas, Guidon (2007), Veloso e Cavalcante (2007) e Buco (2012) revelam a importância da captação de recursos para projetos de qualidade. No caso apresentado por Guidon (2007) e Buco (2012), os recursos foram captados de diferentes fontes, dentre elas instituições de fo- 
mento internacional. No auge do projeto, era oferecida uma série de ações voltadas à comunidade, as quais tinham o intuito de aproximar os participantes do patrimônio e qualificá-los para atuarem profissionalmente na região.

Endere e Zulaica (2015) demonstram a importância do desenvolvimento da pesquisa arqueológica de forma contínua. No caso apresentado, houve a participação da população local, visto que moradores foram capacitados para a pesquisa de campo e para o laboratório. O envolvimento da comunidade com a pesquisa arqueológica propiciou uma melhoria na relação e, consequentemente, incrementou a atração turística. A consolidação das pesquisas arqueológicas desenvolvidas no local possibilitou reforçar os laços e a preservação dos sítios arqueológicos, culminando na abertura de um museu local. De igual forma, Ayala (2015) demonstrou que a forte participação da população local no desenvolvimento de pesquisas arqueológicas no Chile possibilitou a geração de renda e, consequentemente, contribuiu para a valorização do patrimônio e das comunidades locais.

\subsection{Promoção e divulgação dos Atrativos Turístico-Arqueológicos}

A organização da promoção do segmento por meio de um planejamento foi destacada por Walls e Longo (2005), Copeta e Giacomo (2010), Chivu (2013) e Shoup et al. (2014). Chivu (2013) enfatiza que, conjuntamente a outras categorias, é necessário dar importância à promoção do segmento. O nú- mero de visitantes em monumentos e museus na Turquia teve um crescimento significativo, segundo Shoup et al. (2014), o que é um resultado decorrente de campanhas de marketing. Igualmente, Walls e Longo (2005) enfatizam o plano de marketing como estratégia para alavancar o número de visitantes e aumentar a renda em áreas com atrativos de turismo arqueológico. Copeta e Giacomo (2010) destacam a participação em feiras e a elaboração de um material promocional sobre o patrimônio.

\subsection{Monitoramento e Avaliação}

Em sua pesquisa sobre a Península de Tróia, Silveira et al. (2010) descreve as ações tomadas para a salvaguarda do patrimônio local. O estudo apresentou um monitoramento da área. Na pesquisa, os resultados mostraram a importância do acompanhamento constante do local e foram apresentados os monitoramentos realizados entre os anos de 2006 e 2007. O acompanhamento da atividade é imprescindível para a salvaguarda do patrimônio, evitando que este seja exposto aos riscos de destruições antrópicas, ou mesmo sofra impactos naturais. Destacado por Juárez (2002), Guidon (2007), Ramírez et al. (2010), Chamas e Schmidt (2011), Silveira et al. (2011), Buco (2012), Sugiura e Nieto (2014), o monitoramento tem a responsabilidade de mediar os conflitos, os impactos e gerir informações, auxiliando na tomada de decisão.

Uma síntese das dimensões, sua abrangência e as referências dos casos estudados está apresentada de no Quadro 1. 
Quadro 1 - Síntese das Dimensões do Processo de Gestão do Desenvolvimento Turístico-Arqueológico

\begin{tabular}{|c|c|c|}
\hline Dimensões & Abrangência & Referências \\
\hline $\begin{array}{l}\text { Educação Patrimo- } \\
\text { nial }\end{array}$ & $\begin{array}{l}\text { Comunidade escolar } \\
\text { Comunidade geral } \\
\text { Trade turístico } \\
\text { Organismos governamental }\end{array}$ & $\begin{array}{l}\text { Walls e Longo (2005); Guidon } \\
\text { (2007); Veloso e Cavalcanti (2007); } \\
\text { Ramírez et al. (2010); Chamas e Sch- } \\
\text { midt (2011); Buco (2012); Chavarría } \\
\text { (2012); Griffith e Griffith (2012); } \\
\text { Ayala (2015); Endere e Zulaica } \\
\text { (2015). }\end{array}$ \\
\hline $\begin{array}{l}\text { Reconhecimento do } \\
\text { Potencial Turístico- } \\
\text { Arqueológico }\end{array}$ & $\begin{array}{l}\text { Levantamento arqueológico } \\
\text { Capacidade de carga } \\
\text { Percepção da comunidade } \\
\text { Estudo de viabilidade turística }\end{array}$ & $\begin{array}{l}\text { Guidon (2007); Veloso e Cavalcanti } \\
\text { (2007); Copeta e Giacomo (2010); } \\
\text { Chamas e Schmidt (2011); Chavar- } \\
\text { ría, (2012); Griffith e Griffith (2012); } \\
\text { Villalobos, (2014); Shoup et al. } \\
\text { (2014); Sugiura e Nieto (2014); } \\
\text { Ayala (2015); Endere e Zulaica } \\
\text { (2015). }\end{array}$ \\
\hline $\begin{array}{l}\text { Políticas Públicas, } \\
\text { Programas e Parce- } \\
\text { rias Público-Privadas }\end{array}$ & $\begin{array}{l}\text { Registro do patrimônio } \\
\text { Legislação } \\
\text { Documentos de orientação } \\
\text { Iniciativas para valorização } \\
\text { Criação de rotas } \\
\text { Musealização } \\
\text { Manejo e conservação } \\
\text { Parcerias públicas e privadas } \\
\text { Captação de recursos } \\
\text { Pesquisa arqueológica }\end{array}$ & $\begin{array}{l}\text { Buco (2012); Chivu (2013). } \\
\text { Juárez (2002); Veloso e Cavalcanti } \\
\text { (2007); Guidon (2007); Ramírez et } \\
\text { al. (2010); Copeta e Giacomo } \\
\text { (2010); Silveira et al. (2011); Cha- } \\
\text { mas e Schmidt (2011); Buco (2012); } \\
\text { Chavarría (2012); Griffith; Griffith } \\
\text { (2012); Chivu (2013); Villalobos } \\
\text { (2014); Ayala (2015); Endere; Zu- } \\
\text { laica (2015)); Shoup et al. (2014) }\end{array}$ \\
\hline $\begin{array}{l}\text { Promoção e divulga- } \\
\text { ção dos Atrativos Tu- } \\
\text { rístico-Arqueológi- } \\
\text { cos }\end{array}$ & $\begin{array}{l}\text { Campanhas } \\
\text { Estratégias de Divulgação } \\
\text { Plano de Marketing }\end{array}$ & $\begin{array}{l}\text { Walls e Longo (2005); Copeta; Gia- } \\
\text { como (2010); Chivu (2013); Shoup et } \\
\text { al. (2014) }\end{array}$ \\
\hline $\begin{array}{l}\text { Monitoramento/ } \\
\text { Avaliação }\end{array}$ & $\begin{array}{l}\text { Gestão de impactos } \\
\text { Gestão de informações }\end{array}$ & $\begin{array}{l}\text { Juárez (2002); Ramírez et al. (2010); } \\
\text { Chamas e Schmidt (2011); Silveira et } \\
\text { al. (2011); Buco (2012); Sugiura e Ni- } \\
\text { eto (2014); Chivu (2013); Shoup et } \\
\text { al. (2014) }\end{array}$ \\
\hline
\end{tabular}

Assim, com base nos referenciais documentais e bibliográficos e a partir dos estudos de caso apresentados nesse artigo, construiu-se uma proposta que busca integrar os princípios da gestão do turismo e a do patrimônio arqueológico. A síntese bibliográfica, documental e dos casos apresentados permitiram o reconhecimento de cinco dimensões (Figura 1). Tais dimensões se pautam em situações específicas e idiossincrasias locais, conforme pode ser visto em quase todos os casos apresentados nesse estudo. 
Figura 1 - Proposta de Gestão do Desenvolvimento turístico-arqueológico

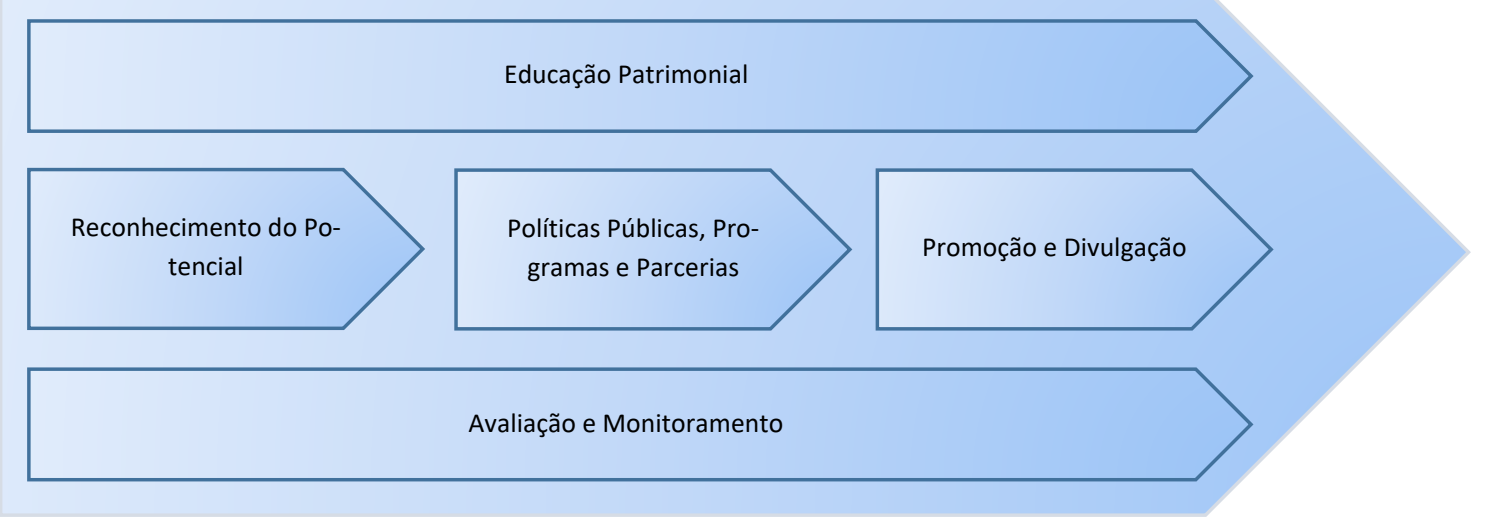

Fonte: Elaborada pelos autores

Em síntese, a dimensão Educação Patrimonial deve estar presente desde a concepção do processo de gestão e será desenvolvida de forma processual e contínua, com ações que visem valorizar o patrimônio, interferindo em todos os demais processos e adaptando-se para atender novas demandas. A dimensão Reconhecimento do Potencial envolve estudos para a compreensão de processos em torno do patrimônio arqueológico e a identificação do potencial turístico da região. A dimensão Políticas Públicas, Programa e Parcerias abrange a análise de ações e medidas para a valorização e proteção de sítios arqueológicos, e a sistematização de proposições para o ordenamento do segmento turístico. A organização da promoção da atividade é abordada pela dimensão Promoção e Divulgação. A dimensão Monitoramento/Avaliação também estará presente no decorrer do processo, pois seu objetivo é gerir as informações, os impactos e os conflitos que possam surgir no decorrer do processo de Gestão.

\section{CONSIDERAÇÕES FINAIS}

O turismo é uma atividade capaz de provocar profundas modificações no território. Quando bem planejado, pode impactar positivamente, somando benefícios. Entre- tanto, o desenvolvimento anômalo poderá ser extremamente danoso para os diferentes meios aos quais está inserido. Em se tratando de turismo arqueológico, a falta de ações que visem ao ordenamento da atividade poderá gerar danos irreversíveis aos sítios arqueológicos.

O modelo proposto se constituiu de cinco dimensões criadas para atender as necessidades da gestão do turismo arqueológico. A intenção desse modelo é a valorização do patrimônio arqueológico e a manutenção da cultura das comunidades circunvizinhas, muitas vezes sem outros recursos econômicos. Diante disso, o modelo norteará o desenvolvimento de uma proposta que propicie maior participação e estimule o interesse da população local pelo patrimônio arqueológico.

O uso desse modelo pode ser um caminho para a valorização e a conservação do patrimônio arqueológico, bem como a integração da comunidade local na gestão e na fruição desse patrimônio. Os estudos de caso demonstraram que muitas ações foram feitas, algumas falharam, outras nem tanto. As pesquisas demonstram que, caso não ocorra uma integração entre poder público e 
sociedade, a efetividade para a salvaguarda do patrimônio arqueológico pode estar ameaçada e, dessa forma, o patrimônio não será preservado para as gerações futuras. Além disso, esse modelo poderá ser extrapolado para outras áreas, caso tenha potencial igual ou maior do que a área investigada. Em linhas gerais, espera-se que o segmento de turismo arqueológico, desenvolvido a partir deste modelo, venha contribuir para a preservação, para a valorização e para a promoção do patrimônio arqueológico.

\section{REFERÊNCIAS}

Ayala, P. R. (2015). O multiculturalismo neoliberal e a arqueologia de contrato no norte de Chile. Revista de Arqueologia, 28(2), 155-171.

Buco, E. (2012). Proteção e conservação de sítios arqueológicos no Parque Nacional da Serra da Capivara. In S. L. Figueiredo, E. Pereira, \& M. Bezerra (Orgs.), Turismo e gestão do patrimônio arqueológico (p. 91-100). Belém: Instituto do Patrimônio Histórico e Artístico Nacional - IPHAN.

Chamas, C. C. (2008). A gestão de um patrimônio arqueológico e paisagístico: Ilha Do Campeche-SC. Dissertação (Mestrado em Geografia), 263 f. Centro de Filosofia e Ciências Humanas, Universidade Federal de Santa Catarina, Florianópolis - SC.

Chamas, C. C., \& Schmidt, A. (2011). Ecotourism and Heritage Conservation. Journal of Coastal Research, 61(Special), 234-241. https://doi.org/10.2112/SI61-001.1

Chavarría, J. C. (2012). Visión, desde los parques arqueológicos de guatemala, del vínculo entre turismo y cultura. Cuaderno del Patrimonio Cultural y Turismo, 19.

Chivu, C. (2013). The Touristic Capitalization Strategies Of Roșia Montană's Heritage - Present And Perspectives. Journal of Tourism - Studies and
Researche in tourism, (16), 43-51.

Copeta, C., \& Giacomo, E. S. De. (2010). Promotion of Destinations of Excellence: Reevaluation of a Medieval Tourist Route - Guidone ' s Itinerary ( 1119 a.d.). Tékhne - Polytechnical Studies Review, 8(14), 111-121.

Endere, M. L., \& Zulaica, M. L. (2015). Socio-cultural sustainability and "Buen Vivir" (Good Living) at heritage sites: assessment of the Agua Blanca case, Ecuador. Ambiente \& Sociedade, 28(4), 259-284. https://doi.org/http://dx.doi.org/10.1590/18094422ASOC1317V1842015

Griffith, C. S., \& Griffith, L. M. (2012). Partnerships in Archaeotourism: the Future of Cueva Borbon, Dominican Republic. Chungara-Revista De Antropologia Chilena, 44(3), 523-532. https://doi.org/10.4067/S071773562012000300014

Guidon, N. (2007). Parque Nacional da Serra da Capivara: modelo de preservação do patrimônio arqueológico ameaçado. Revista do Patrimônio Histórico e Artístico Nacional, 33, 75-93.

Icomos. Carta de Veneza, de maio de 1964. Carta internacional sobre conservação e restauração de monumentos e sítios (1964). II Congresso internacional de arquitetos e técnicos dos monumentos históricos, ICOMOS - Conselho Internacional dos Monumentos e Sítios, Veneza. Recuperado de http://portal.iphan.gov.br/uploads/ckfinder/arquiv os/Carta de Veneza 1964.pdf

Icomos. Declaração de Sofia, 09 de outubro de 1996. Defende o pluralismo cultural (1996). XI Assembleia Geral do ICOMOS - Conselho Internacional dos Monumentos e Sítios, Sofia, Bulgária. Recuperado de http://portal.iphan.gov.br/uploads/ckfinder/arquiv os/Declaracao de Sofia 1996.pdf

Icomos/Icahm. Carta de Lausanne, de outubro de 1990. Carta para a proteção e a gestão do patrimônio arqueológico. (1990). IX Assembleia Geral do ICOMOS - Conselho Internacional dos Monumentos e Sítios, ICAHM - Comitê Internacional para a Gestão do Patrimônio 
Arqueológico, Lausanne, Suiça. Recuperado de http://portal.iphan.gov.br/uploads/ckfinder/arquiv os/Carta de Lausanne 1990.pdf

Hall, C. Michael. A typology of governance and its implications for tourism policy analysis. Journal of Sustainable Tourism. Vol 19, may/june, 2011.

OEA. Normas de Quito, conservação e utilização de monumentos e sítios de interesse Histórico e Artístico. (1967). Reunião OEA - Organização dos Estados Americanos, de dezembro de 1967, Quito, Equador.

https://doi.org/10.1017/СВ09781107415324.004

Oliveira, Antonio Gonçalves de; Pisa, Beatriz Jackiu. IGovP: índice de avaliação da governança pública instrumento de planejamento do Estado e de controle social pelo cidadão. Revista de Administração Pública - Rio de janeiro 49 (5): 12631290, set/out 2015.

Pulido-Fernandez, Juan Ignacio; Pulido-Fernandez, María de la Cruz. Proposal for an Indicators System of Tourism Governance at Tourism Destination Level. Springer Science + Business Media. Dordrecht, 2017.

Ramírez, M. T., Novella, R., \& Barrera-Bassols, N. (2010). Reconciliando naturaleza y cultura: una propuesta para la conservación del paisaje y geositios de la costa norte de Michoacán, México. Revista de Geografía Norte Grande, 46, 105-121.

Seixas, João; Mas, Abel Albert I. Urban Governance in the South of Europe: cultural identities and global dillemmas. Análise Social. N.197. Lisboa, 2010.

Shoup, D. D., Baraldi, S. B., \& Zan, L. (2014). A centralized decentralization: outsourcing in the Turkish cultural heritage sector. International Journal of Cultural Policy, 20(1), 54-77. https://doi.org/10.1080/10286632.2012.731051

Silveira, T. M., Kraus, N. C., Psuty, N. P., \& Andrade, F. (2011). Beach Nourishment on Troia Peninsula, Portugal. Journal of Coastal Research, 59(SI), 173180. https://doi.org/10.2112/SI59-018.1

Sugiura, Y. Y., \& Nieto, R. H. (2014). Una reflexión sobre la preservación del patrimonio arqueológico: el caso de los sitios de escala menor en el estado de México. Anales de Antropología, 48(2), 75-95. https://doi.org/10.1016/S0185-1225(14)70244-9

Unesco. Recomendação relativa à salvaguarda da beleza e do caráter das paisagens e sítios (1962). Conferência Geral da Organização das Unidas para

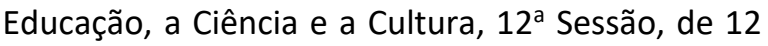
de dezembro de 1962, Paris, França. https://doi.org/10.1017/CBO9781107415324.004

Veloso, T. P. G., \& Cavalcanti, J. E. A. (2007). O turismo em sítios arqueológicos: algumas modalidades de apresentação do patrimônio arqueológico. Revista de Arqueologia, 20, 155-168. Recuperado de http://periodicos.ufpb.br/index.php/ra/article/vie $\mathrm{w} / 1684$

Villalobos, C. A. (2014). ¿ Por qué en Sonora no hay arqueología ? Nacionalismo y turismo en billetes de banco y folletos de viaje. Región y Sociedade, 26(59), 215-253.

Walls, S. G., \& Longo, N. (2005). Mesa Verde Centenial Celebration. Journal of Teaching in Travel \& Tourism, 5(4), 15-23. https://doi.org/10.1300/J172v05n04

Wang, Jingchuan; LI, Tianyuan. Review on Tourist Destination Governance in Foreign Countries. Tourism Tribune. Vol 28, n6. 2013.

Zahra, Anne Louise. Rethinking regional Tourism governance: the principle of subsidiarity. Journal of Sustainable Tourism. Vol. 19. N. 4-5, May, 2011.

\section{Informações sobre os autores}

\section{Geovan Martins Guimarães}

Mestre e Doutor em Turismo e Hospitalidade pela Universidade do Vale do Itajaí (UNIVALI). Graduado em Turismo e Hotelaria pela Universidade do Sul de Santa Catarina (UNISUL). Atualmente é Professor Associado da Universidade do Sul de Santa Catarina (UNISUL).

E-mail: geovan@ymail.com

ORCID - https://orcid.org/0000-0002-9659-8240 


\section{Francisco Antonio Anjos}

Doutor em Engenharia e Mestre em Geografia pela Universidade Federal de Santa Catarina (UFSC). Graduado em Geografia pela Universidade do Vale do Itajaí (UNIVALI). Professor Titular da Universidade do Vale do Itajaí (UNIVALI).

E-mail: anjos@univali.br

ORCID: https://orcid.org/0000-0002-4044-4656

\section{Deisi Scunderlick Eloy de Farias}

Mestre e Doutora em História pela Pontifícia Universidade Católica do Rio Grande do Sul. Professora Titular da Universidade do Sul de Santa Catarina (UNISUL).
Email: deisiarqueologia@gmail.com

Orcid: https://orcid.org/0000-0002-6036-9948

\section{Marcos Arnold Junior}

Mestre e Doutor em Turismo e Hotelaria pela Universidade do Vale do Itajaí (UNIVALI). Graduado em Turismo e Hotelaria pela Universidade do Vale do Itajaí (UNIVALI). Atualmente é Professor Associado em Turismo e Hotelaria pela Universidade do Vale do Itajaí (UNIVALI).

Email: marcosarnhold@gmail.com

Orcid: https://orcid.org/0000-0002-1721-9733 